6

\title{
Prebivalstvo in gospodarski viri v tržaškem kraškem zaledju (I6.-20. stoletje)
}

\author{
Aleksej Kalc \\ Inštitut za slovensko izseljenstvo in migracije \\ ZRC SAZU \\ Novi trg 2, 1000 Ljubljana \\ AKalc@zrc-sazu.si \\ Fakulteta za humanistične študije \\ Univerza na Primorskem \\ Titov $\operatorname{trg}$ 5, 6000 Koper \\ aleksej.kalc@fhs.upr.si
}

\section{Uvod}

V razvoju prebivalstva na Slovenskem so v novem veku in do konca avstrijskega obdobja opazne nekatere deželne razlike in specifike. Za ozemlje Avstrijskega primorja so značilne višje stopnje poročnosti in natalitete ter živahnejša rast prebivalstva kot $\mathrm{v}$ drugih slovenskih deželah (Blaznik idr. 1970; Zwitter 1936). Zgodovinarji to pripisujejo zemljepisni legi tega prostora na stičišču s Furlanijo in bliže morju, kjer sta intenzivnejša trgovina in promet ustvarjala ugodne predpostavke tako za tržno agrarno ekonomijo kot za neagrarne oblike gospodarskega udejstvovanja. Od 18. stoletja dalje je imel pri tem pomembno vlogo Trst, bodisi kot neposredni trg za proizvode in usluge bodisi kot pospeševalec gospodarskih dejavnosti v svojem neposrednem in širšem zaledju. Demografija mesta je bila tesno povezana z zaledjem, saj je rast tržaškega prebivalstva slonela na množičnem priseljevanju, ki je v veliki meri izviralo iz sosednih dežel (Kalc 2008). Ekspanzija Trsta pa se je bolj ali manj poudarjeno odražala $\mathrm{v}$ razvoju prebivalstva in $\mathrm{v}$ demografski fiziognomiji prostora, ki ga je obdajal.

Ta prispevek obravnava značilnosti razvoja prebivalstva v neposredni tržaški okolici od srede 16. stoletja do prve svetovne vojne. Ta območja so bila v starejši fazi obravnavanega obdobja povezana z ekonomijo komunskega Trsta, nato pa posredno in neposredno zajeta $\mathrm{v}$ proces nastajanja in razvoja glavnega avstrijskega pristanišča ter enega največjih avstrijskih mest. Namen je ugotoviti kontinuitete in premike $\mathrm{v}$ demografiji ter izpostaviti 
razmerja med demografskimi tendencami in značilnostmi ter ekonomijo tega dela podeželja. Upoštevani sta dve območji, in sicer podeželski del tržaškega občinskega ozemlja, ki se razteza okrog mesta, in območje neposredno za tržaško občinsko mejo, točneje ozemlje prafare Povir.

Podeželje tržaške občine, imenovano »teritorij« (territorio) in v 19. stoletju v slovenščini »okolica«, je bilo sestavljeno iz dela na flišnatem in naplavinskem svetu pod kraškim robom in dela na kraški planoti. Del pod kraškim robom je tvoril zgodovinski tržaški ager, kjer so imeli mestni posestniki svoje vinograde, oljčne nasade in druge agrarne površine, ki so skupaj s solinami predstavljale pomembne postavke tržaške ekonomije. Ta del teritorija je bil do 19. stoletja redko poseljen $\mathrm{z}$ razpršenimi hišami ali manjšimi gručastimi zaselki. Prebivalstvo so sestavljali mali kmečki posestniki in predvsem kmetje, ki so obdelovali zemljo mestnih posestnikov na podlagi kolonatskih ali drugih zemljiških najemniških razmerji in kot kmečki delavci. Prebivalstvo je $\mathrm{v}$ tem delu podeželja, imenovanem »soseske« (it. contrade), začelo naraščati v 18. stoletju s priseljevanjem kmetov iz zaledja, ki so od mestnih lastnikov prevzemali zemljišča in si ustvarjali lastna posestva. Ker je bila večina naseljencev iz slovenskega območja in se je slovenska posest razširila vse do mesta, so ta proces tržaški italijanski zgodovinarji opredelili kot »slavizacijo" tržaškega podeželja. Soseske so bile Barkovlje, Kjadin, Spodnja in Zgornja Čarbola, Kolonja, Greta, Vrdela, Rojan, Rocol, Škorklja in Spodnja ter Zgornja Sveta Marija Magdalena. V območje sosesk se je v 18. in 19. stoletju s svojimi novimi četrtmi širila tudi mestna naselbina in premikala mejo med urbaniziranim območjem in podeželjem. $V$ celoti pa je večinoma ohranjalo podeželski in kmečki značaj, s tem, da je s časom družbena struktura v kmečkih zaselkih dobila polkmečke poteze (Kalc 2009, 3-4).

Poselitev zunanjega dela tržaškega teritorija so sestavljale sklenjene kmečke vasi na kraški planoti, na nadmorski višini od 290 do 350 metrov, in sicer Križ, Prosek, Kontovel, Opčine, Bani, Trebče Gropada, Padriče, Bazovica in Lipica. V ta del teritorija, imenovan "vasi« (it. ville), je sodil zaradi enake naselbinske tipologije in statusa tudi Škedenj, ki je bil vaška enklava na flišnatem svetu na območju sosesk tik ob morju. Večina vasi je nastala $\mathrm{v}$ srednjem veku, ko so si tržaški nemški škofje prizadevali kolonizirati ozemlje škofije in so nanj naseljevali slovansko prebivalstvo. V zgodovinskih dokumentih so prvič omenjene v 13. in 14. stoletju. Samo Kontovel in Bani sta $\mathrm{z}$ začetka 15. stoletja, nastanek Padrič pa sega na začetek 17. stoletja (Krajevni leksikon 1990). Prebivalci vasi so bili mali 
kmetje, povezani v vaške skupnosti. Z izjemo Škednja, ki se nahaja bliže mestu in je v drugi polovici 19. stoletja na njegovo območje segla industrializacija, je ostalo območje vasi izvzeto iz procesa urbanizacije. Njihovo gospodarstvo, demografski in družbeni razvoj pa so bili tesno povezani $\mathrm{z}$ mestom (Kalc 2009, 3-4).

Ozemlje prvotne župnije Povir, ki nam služi za primerjavo, je glede tipologije poselitve podobno kraškemu delu tržaškega podeželja, le da je bolj oddaljeno od mesta. Za razliko od tržaških vasi tudi ni sodilo pod neposredno mestno upravo ter pod pravni red prostega pristanišča. To ozemlje s 16 vasmi so po letu 1784 cerkvenoupravno reorganizirali in razdelili med župnijo Povir, pod katero so spadale še Brestovica, Gorenje, Merče, Plešivica in Žirje, dušnopastirske postaje Sežana s Šmarjami, Danami in Orlekom, Divača z Ležečami in Štorje s Podbrežami, Senadolami in Majcni. Tudi te vasi so srednjeveškega izvora. Sežana, Šmarje in Dane so prvič omenjene v 11. stoletju, Ležeče, Dolenje in Gorenje v 13., Divača, Štorje, Podbreže in Senadole pa v 15. stoletju, ${ }^{1}$ so pa tudi te starejšega datuma. To cerkvenoupravno ozemlje smo izbrali zaradi obstoja kolikor toliko nepretrganega niza podatkov o rojstvih in smrtih od srede 17. stoletja do prve svetovne vojne.

\section{O virih}

Preučevanje razvoja prebivalstva $\mathrm{v}$ večstoletni časovni perspektivi se vselej sooča s pomanjkanjem, $\mathrm{z}$ nedoslednostjo in ozemeljsko neprimerljivostjo podatkov. To velja posebno za čas do 18. stoletja, preden je država začela bolj ali manj redno popisovati prebivalstvo po enovitih kriterijih in na celotnem državnem ozemlju. V tem stoletju so tudi cerkvene matrike postale nazornejše in teritorialno usklajenejše s popisnimi teritorialnimi enotami. Pogosto pa so od štetij znani le rezultati za dežele ali večje teritorialne enote, medtem ko so se podatki za manjša upravna območja in posamezne kraje skupaj s popisno dokumentacijo izgubili. Tako na primer za ljubljansko škofijo razpolagamo s podatki prvega vsedržavnega avstrijskega štetja iz leta 1754 in za Kranjsko s podrobnimi podatki konskripcije iz leta 1778 (Valenčič 1962; Valenčič 1996). Za Avstrijsko primorje pa so se ohranili le podatki o številu hiš po okrajih na Goriškem iz leta 1754 (Della Bona 1856; Iancis 2001, 25). Ohranil pa se je, na primer, popis duš za Goriško iz leta

Kos, Gradivo za historično topografijo Primorske, Rokopisna zapuščina M. Kosa, ZIKM ZRC. 
1566, ki ponuja sliko prostorske, demografske in družbene strukture prebivalstva (Panjek 2012).

Podobni problemi se postavljajo tudi pri območju, ki je predmet te obravnave. Za srednjeveško obdobje in večji del novega veka so na voljo občasni in delni podatki o prebivalstvu, in to le za nekatere kraje. Za tržaški teritorij sta za zgodnji novi vek pomembna dva vira, in sicer t. i. "pertikacije» (it. perticazioni). Gre za izmere agrarnih površin, ki jih je opravila tržaška mestna občina leta 1525 in v letih 1647-48, da bi ugotovila stanje vinogradov in obdelanih kmečkih zemljišč v okoliškem delu občinskega ozemlja (Pahor 1987; Merkú 1994). Izmero je narekoval »nered«, ki je nastajal, ker so okoliški kmetje širili svoje vinograde in zanemarjali vinograde, ki so jih obdelovali za mestne lastnike, najbrž pa tudi, ker sta širjenje vinogradniških površin in večanje proizvodnje povzročala padanje cen vina in škodila gospodarskim interesom mestnih lastnikov vinogradov. Oba registra pertikacij, ki ju objavlja Montanelli (1905), navajata tudi kmečke posestnike, na podlagi katerih je mogoče oceniti število prebivalcev posameznih vasi.

Prvi podrobni popisi prebivalstva tržaškega teritorija so šele konskripcije iz sedemdesetih let 18 . stoletja. Prva je iz leta 1773 , ko so na tržaškem podeželju tudi oštevilčili hiše, in od nje so se ohranili podatki za območje sosesk. Druga, podrobnejša, je iz let 1777-78 in predstavlja prvi zgodovinski vir $\mathrm{z}$ enovitimi podatki o prebivalstvu celotnega tržaškega teritorija. Ohranile so se tudi populacijske knjige, to so registri prebivalstva $\mathrm{z}$ imeni in strukturnimi podatki popisancev, s pomočjo katerih so vodili evidenco vojaških zavezancev (Kalc 2008). Od konskripcijskih popisov, ki so jih izvedli v letih $1800,1810,1818$ in 1846 , so se za tržaški teritorij ohranili le sumarni podatki za posamezne vasi, medtem ko so od leta 1857 na voljo podatki modernih štetij (Montanelli 1905). Za območje povirske župnije se naši popisni podatki o prebivalstvu začnejo šele v 19. stoletju. Prvi so iz operatov franciscejskega katastra in se nanašajo na konskripcijo iz leta 1827 , nadaljnji pa so iz ljudskih štetij od leta 1869 do 1910 . Tako na območju vasi tržaškega teritorija kot na povirskem območju se cerkvenoupravne meje $\mathrm{v}$ glavnem ujemajo $\mathrm{s}$ političnoupravnimi, tako da je mogoče primerjati razpoložljive popisne podatke s podatki o naravnem gibanju iz cerkvenih matičnih knjig. To ne velja za območje sosesk tržaškega teritorija, ki je cerkvenoupravno spadalo pod mestne župnije in na njem ni mogoče usklajevati podatkov iz cerkvenih matrik s podatki štetij. Zaradi prodiranja urbanizacije in spreminjanja upravnih mej v popisnih podatkih ni 
mogoče niti ločevati podeželskega od ostalega prebivalstva in ga primerjati v času. Zato se demografska analiza osredotoča na obe kraški območji, s poudarkom na tistem v tržaški občini. Dogajanje na povirskem območju bo upoštevano predvsem za primerjavo in ugotavljanje podobnosti oz. razlik v demografskem dogajanju na posameznih delih tržaškega kraškega zaledja. Območje sosesk bo zajeto $\mathrm{v}$ razpravo o vprašanjih integrirane kmečke ekonomije, za kontekstualizacijo demografske analize pa bodo prikazane tudi demografske razvojne poteze mestne naselbine. ${ }^{2}$

\section{Demografski razvoj v kraškem delu tržaškega teritorija}

Prvi zanesljivi podatki o prebivalstvu celotnega kraškega dela tržaškega teritorija segajo v leta 1647-48. Takrat so ob izmerah obdelovalnih zemljišč popisali tudi 309 kmetov družinskih poglavarjev. Če domnevamo, da so družine štele povprečno po pet članov, smemo število prebivalstva v tistem obdobju oceniti na 1.545, prebivalstvo po posameznih krajih pa, kot je navedeno v tabeli 6.1. Za vasi Križ, Prosek in Kontovel lahko na enak način ocenimo prebivalstvo tudi za leto 1525 , ko se je popis nanašal samo na te kraje. Te tri vasi v severozahodnem delu teritorija so bile tisti čas najobljudenejše. To je povezano $\mathrm{z}$ vinogradništvom, ki je bilo najpomembnejša agrarna kultura in ena pomembnejših ekonomskih panog na Tržaškem. Ti kmetje so obdelovali svoje vinograde in vinograde mestnih lastnikov na najrodovitnejši zemlji, v bregu pod kraškim robom, ki strmo pada do morske obale. Zaradi ugodnih klimatskih in pedoloških pogojev je bila tu vinska trta prisotna že $\mathrm{v}$ rimskem času in obrodila znamenito vino, imenovano pucinum (Pahor 1987) Od srednjega veka dalje so tukajšnje terasaste vinogradniške površine širili $z$ nadaljnjim sistematičnim paštnanjem in na njih se je rojevalo najboljše tržaško vino, ki je šlo v promet tako v mestu kot na tujem (Kalc 2005). Na kraški planoti so se prebivalci teh vasi ukvarjali s poljedelstvom in živinorejo, v Križu in na Kontovelu pa tudi z ribolovom ob severozahodnih obalah tržaškega zaliva.

Preostali, obsežnejši del ozemlja kraškega dela tržaškega teritorija, ki je bil zelo kamnit in pust, delno tudi poraščen z gozdom, pa je bil v 16 . stoletju zelo redko poseljen. Tu ni bilo pogojev za kvalitetnejše kulture kot v strmih in za delo napornih, a zavetnih in močno osončenih legah

2 Neobjavljeni viri, uporabljeni v tem prispevku, so iz: ZAŽB; ŠAK, Župnija Povir, Župnija Sežana, Župnija Divača, Kaplanija Štorje; AGT, Archivio Magistratuale. Za demografske podatke iz franciscejskega katastra glej prispevek Nataše Kolega v tej knjigi. 
pod kraškim robom. Kmetje so večinoma razpolagali samo z zemljišči na kraških tleh. Nižje letne temperature, izpostavljenost burji, tanka zemeljska plast, omejen obseg agrarnih površin, ki jih je bilo treba pridobivati s trebljenjem kamenja, in pomanjkanje vode, vse to ni dopuščalo bogatejših kultur in boljšega trženja pridelkov, pač pa le pridelavo poljščin in skromno živinorejo. Vse to se odraža tudi v manjšem številu prebivalstva na tem delu tržaškega teritorija.

Obdobje od srede 15. do začetka 17. stoletja je bilo za Trst sploh zelo viharno, čemur je pripisati nihanje števila prebivalstva mesta in njegove okolice. Območje je bilo pod stalnimi napadi Benečanov, ki so obvladovali Jadransko morje in večkrat poškodovali Trst in njegovo okolico. Ti spopadi so se končali $\mathrm{z}$ mirom med Benetkami in avstrijskim cesarjem, sklenjenim leta 1617. Na začetku 17. stoletja so dosegli svoj višek in takrat je število mestnega prebivalstva padlo na najnižjo stopnjo (okrog 3.0oo). Pomorska dejavnost in trgovina mesta sta bili zaradi tega prizadeti in sta nihali. Na število prebivalstva so vplivale tudi razne lakote in epidemične bolezni. Kuga je periodično terjala svoj smrtni davek. Podatki, ki so nam jih zapustili sodobni kronisti, in ocene na podlagi dinamike rojstev kažejo, da je bila v 16. stoletju amplituda nihanja števila prebivalstva zelo izrazita. Z nastopom mirnejšega obdobja po letu 1617 so se gospodarske razmere izboljšale, čeprav se je še naprej čutil negativni vpliv Benetk, ki so tržaško trgovino in pomorstvo na razne načine omejevale. Prav to je spodbujalo rast agrarne ekonomije, predvsem vinogradništva, in solinarstva, ki sta bili nosilni panogi tržaške ekonomije (Montanelli 1905, 16-22).

Po letu 1617 je število prebivalstva mesta začelo naraščati in doseglo v štiridesetih letih okrog 5.000 prebivalcev. Nato dinamika rojstev sredi stoletja ponovno upada, kar je bilo povezano s takratno veliko lakoto. Sledila je ponovna rast, proti koncu stoletja pa spet upadanje in nato stagnacija števila prebivalstva, ki je trajala vse do proglasitve prostega pristanišča leta 1719 (Montanelli 1905, 26-33). S tem se začne nova doba demografskega razvoja mesta, ki jo označuje nepretrgana in vse večja rast prebivalstva, povezana s prostim pristaniščem. Glavni dejavnik te rasti je bilo množično priseljevanje iz ožjega in širšega zaledja mesta, ki je ponujalo gospodarske priložnosti za najrazličnejše poklicne in delovne profile ter ki ga je oblast spodbujala s posebnimi privilegiji in namenskimi politikami (Kalc 2008). Priseljence iz širšega zaledja in oddaljenejših krajev je pritegovalo predvsem mesto. Ugodne razmere za naseljevanje pa so z gospodarsko ekspanzijo mesta nastale tudi v njegovi agrarni okolici. Zaradi širjenja poselitve in 
Tabela 6.r: Prebivalstvo kraških vasi tržaškega teritorija od leta I525 do leta I9ı

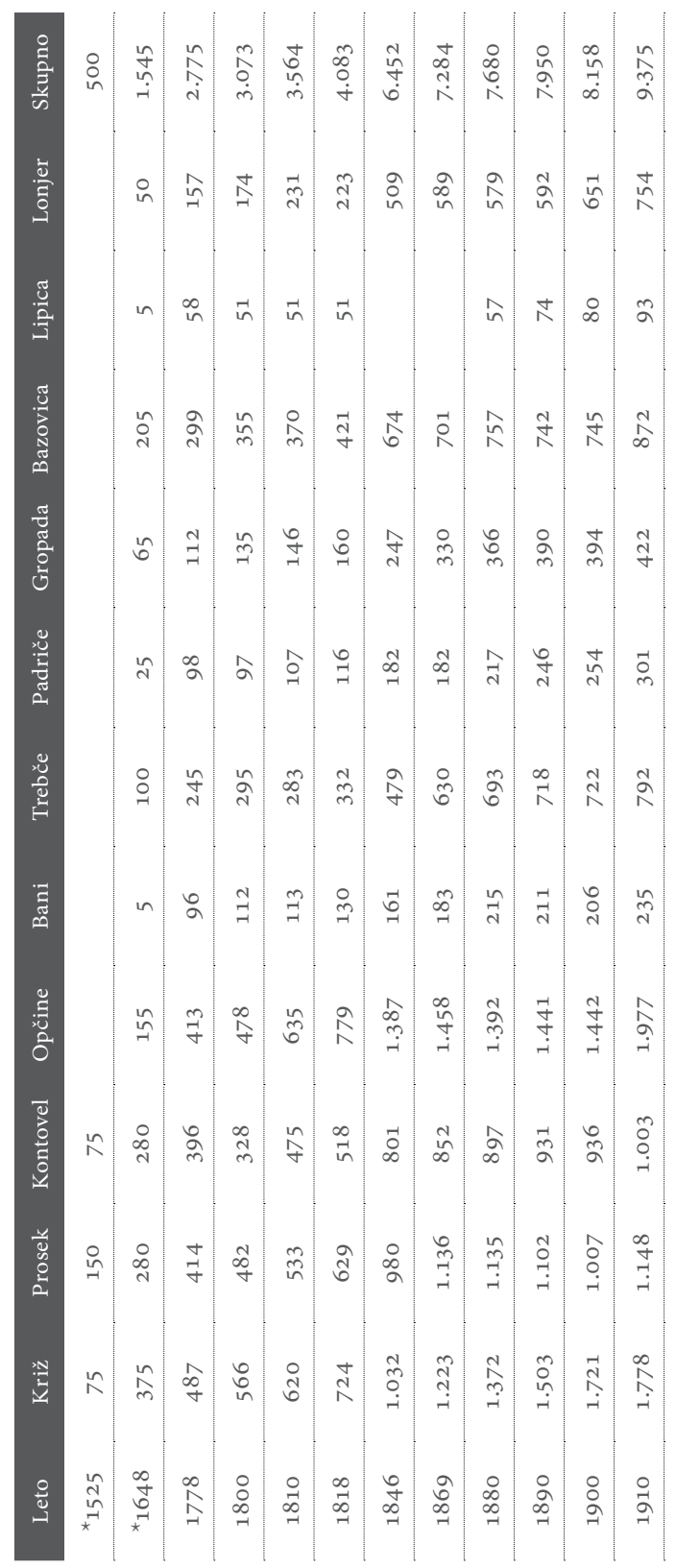

\section{* ocena}

Viri: Montanelli 1905; Brodmann ı82ı; Kalc 2008; Državna ljudska štetja ı869-1910. 
povečanja števila prebivalstva so $\mathrm{v}$ soseskah $\mathrm{v}$ šestdesetih letih uvedli tudi funkcijo župana, ki je v kraškem delu teritorija načeloval vaškim skupnostim in bil vezni upravni člen s tržaško občino že v srednjem veku (Navarra 1993; Kalc 2009).

V prvi polovici 16. stoletja je bilo, kot rečeno, prebivalstvo tu maloštevilno in razporejeno podobno kot sredi 17. stoletja. Najbrž je bil delež prebivalstva v zahodnih vaseh Prosek, Kontovel in Križ še večji, če pomislimo, da v vzhodnem delu še ni bilo Padrič. Na podlagi razmerja med zahodnim in preostalim kraškim delom iz leta 1648 smemo sklepati, da je v srednjem in vzhodnem delu ozemlja v prvi polovici 16. stoletja živelo kakih 200 prebivalcev. Do srede 17. stoletja pa je prebivalstvo celotnega kraškega območja kljub negativnim vplivom zgoraj opisanih dogajanj živahno naraščalo in se, kot kažejo podatki druge pertikacije, potrojilo. $\mathrm{V}$ tem času je prihajalo do priselitve novih kmečkih družin, ki so se naseljevale tudi na območju pod kraškim robom. Ker so priseljenci uvajali živinorejo, ki je bila po mestnih statutih pod kraškim robom prepovedana, so jih mestne oblasti včasih tudi odgnale (Montanelli 1905, 34-5). Občutno demografsko rast je $\mathrm{v}$ tem dolgem obdobju doživljalo tudi širše tržaško zaledje. V drugi in tretji četrtini 16. stoletja ji je botrovala repopulacija območja, ki so ga prizadeli zadnji večji turški vpadi konec 15. stoletja (Panjek 2015, 100).

Naslednji in prvi natančni podatki o številu prebivalstva celotnega tržaškega teritorija so iz let 1777-78. Konskripcijski popis je takrat na območju kraških vasi naštel 2.775 prebivalcev (Kalc 2008). Ker razpolagamo od srede 17. stoletja s podatki naravnega gibanja prebivalstva vasi (Montanelli 1905, 80-7), lahko ocenimo število in razvoj prebivalstva v dolgem obdobju od srede 17. do sedemdesetih let 18. stoletja. Ocena temelji na statistiki rojstev oz. rodnosti, ki se v dolgem obdobju giba okrog dokaj konstantnih povprečnih stopenj. Na podlagi števila rojstev lahko izračunamo približen obseg prebivalstva $\mathrm{v}$ posameznih obdobjih. Ocena razvoja prebivalstva od srede 17. stoletja do druge polovice sedemdesetih let 18. stoletja je prikazana $v$ grafu 6.1. Izračunana je na podlagi povprečnega števila rojstev po petletjih s pomočjo razmerja 1 rojenega na 27,59 prebivalcev, ki odgovarja stopnji rodnosti 36,25 promila. Koeficient je pridobljen na podlagi razmerja med številom prebivalstva iz let $1647 / 48$ in povprečnim številom rojstev petletja $1658-62$, najbližjega, za katerega so v nizu rojstev na voljo verodostojni podatki. 


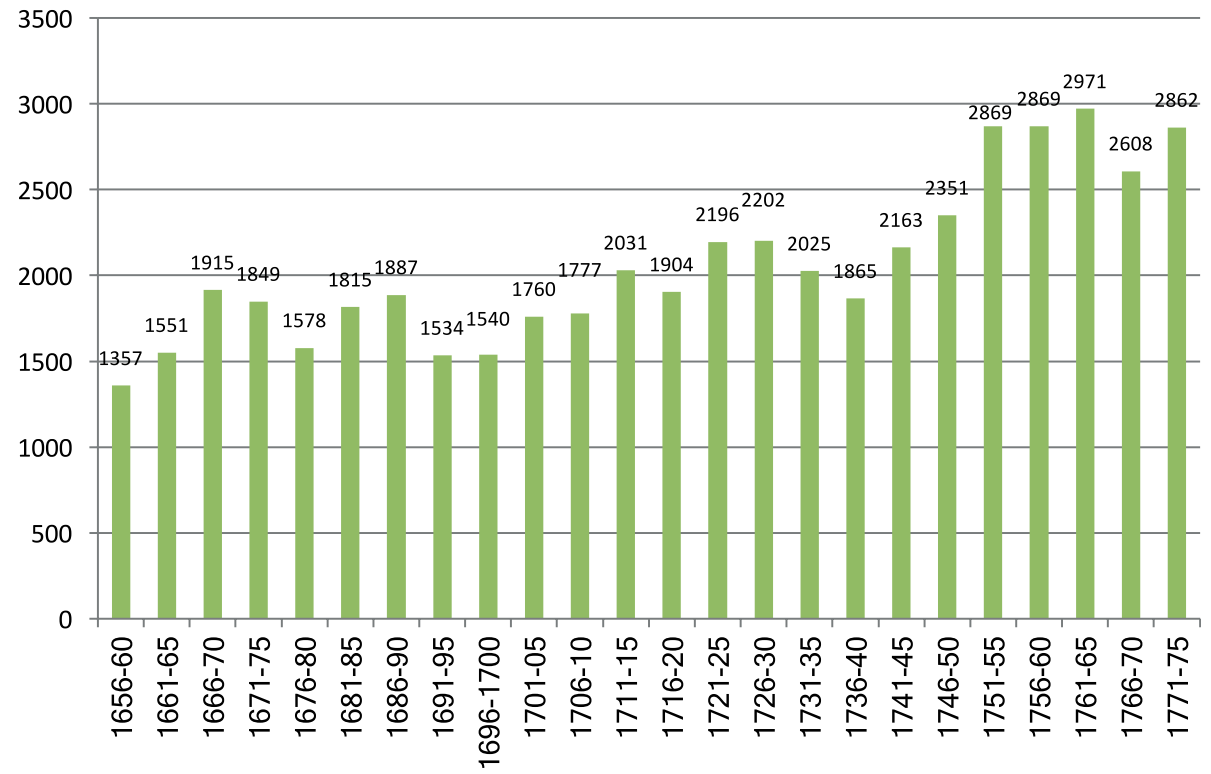

Graf 6.I: Ocena števila prebivalstva kraškega dela tržaškega teritorija na podlagi povprečnega števila rojstev (1656-1775)

Vir: Montanelli 1905.

Gibanje števila prebivalstva sovpada s prej opisano dinamiko demografskega razvoja mesta. Za prvo polovico 17. stoletja nimamo podatkov o rojstvih. Sklepati pa smemo, da je od konca vojn z Benetkami in $\mathrm{z}$ madridskim mirom 1617 tudi $v$ tržaški okolici, kot $\mathrm{v}$ mestu, število prebivalcev naraščalo vse do srede stoletja. Leta 1650 je območje pestila velika kriza in lakota, ki je nedvomno negativno vplivala na demografski razvoj. Trend naraščanja se je nato nadaljeval do konca šestdesetih let, vendar je bila $\mathrm{v}$ nadaljevanju rast zelo nihajoča in negotova. $\mathrm{V}$ sedemdesetih letih je prebivalstvo nazadovalo, $v$ osemdesetih spet naraščalo, $v$ devetdesetih pa zopet upadlo. Na začetku 18. stoletja je obseg prebivalstva vasi, kljub periodičnim vmesnim naraščanjem, ostajal bolj ali manj enak obsegu sredi 17. stoletja.

Močnejša rast je nastopila $\mathrm{v}$ prvih desetletjih 18. stoletja, zlasti po ustanovitvi prostega pristanišča leta 1719, ko se za Trst začenja nova zgodovinska doba. $V$ prvi polovici 18. stoletja je prebivalstvo naraščalo za povprečno 8,5 promilov na leto. Že v drugi polovici tridesetih in prvi polovici štiridesetih let pa je nastopil krizni moment, ki je prizadel tudi rast mesta in je bil 
povezan $\mathrm{z}$ vrsto težav upravne narave ter samih institucionalnih nastavkov prostega pristanišča. $Z$ reformo uprave Avstrijskega primorja in uvedbo ustanov za razvijanje prostega pristanišča (Faber 1995) je v petdesetih letih skupaj z mestnim zopet naraščalo tudi prebivalstvo okolice in kraških vasi v njej.

$\mathrm{V}$ drugi polovici šestdesetih let je spet nastopil krizni moment, ki se odraža v razvoju prebivalstva. Šele v sedemdesetih letih se nato začne močnejša demografska rast. Ocenjevanje obsega prebivalstva s pomočjo podatkov o rojstvih daje za sedemdeseta leta višje vrednosti od rezultatov konskripcije iz leta 1777-78. Domnevati smemo, da je bilo tudi v prejšnih desetletjih dejansko število prebivalstva nižje od prikazanega v grafu, ker se je v tem obdobju nekoliko spremenilo razmerje med prebivalstvom in rojstvi. Na podlagi podatkov konskripcijske statistike izhaja, da je na koncu sedemdesetih let prišlo po eno rojstvo na vsakih 22,75 prebivalcev. Stopnja natalitete se je torej dvignila na okrog 44 promilov. Rodnost je $\mathrm{v}$ 18. stoletju močno narasla tudi v mestu. Tu je v prvih desetletjih 18 . stoletja znašala okrog 32 promilov, po zagonu proste luke pa 40 promilov. To je bilo povezano $\mathrm{s}$ priseljevanjem in povečanjem segmenta prebivalstva $\mathrm{v}$ demografsko aktivni starosti. Koeficient, veljaven sredi 17. stoletja, smo uporabili vse do sedemdesetih let 18. stoletja kot pomagalo za prikaz dolgoročne dinamike rasti števila prebivalstva.

Nadaljnja razprava temelji na podatkih štetij, do leta 1846 konskripcijskih, od leta 1869 dalje modernih popisov. Rezultati konskripcij so zaradi metodoloških razlogov izkazovali nekoliko nižje število prebivalstva od dejanskega (Zwitter, 1936, 37). Kljub temu podatki obravnavanih vasi bistveno ne odstopajo od realnosti. Za določena obdobja imamo na voljo tudi statistiko naravnega gibanja prebivalstva.

$\mathrm{V}$ zadnjih treh desetletjih 18. stoletja se je povprečno število rojstev stopnjevalo in naraslo za skoraj 60 \% (od povprečno 103, 8 do 161,6 na leto). Ta trend pa se ne odraža $v$ enakovrednem naraščanju števila prebivalstva. To je naraslo za slabih $11 \%$, ali povprečno 4,6 promila na leto. Iz arhivske dokumentacije izvemo, da je bila konskripcija za leto 1800 posebno problematična in rezultati so pomanjkljivi (Montanelli 1905). Realno število prebivalstva je bilo zanesljivo višje, vendar ne toliko, da bi se povsem skladalo $\mathrm{z}$ rastjo rojstev. 


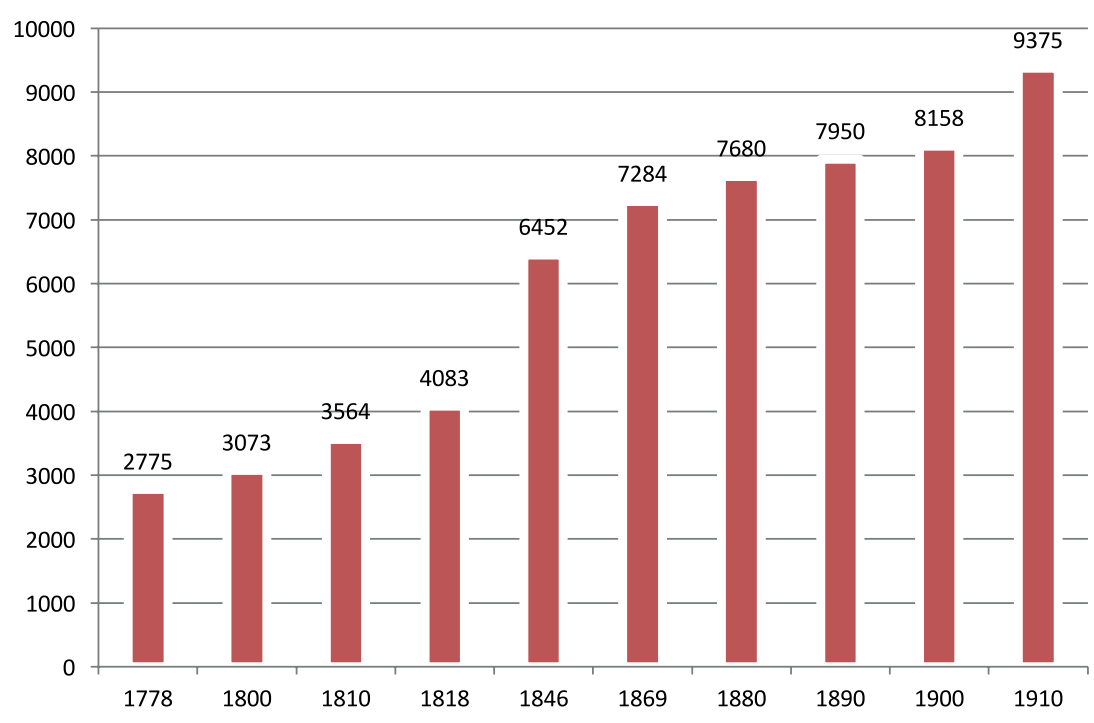

Graf 6.2: Razvoj števila prebivalstva kraškega dela tržaškega teritorija v obdobju i778-19ı Vir: Kalc 2008; Montanelli 1905; Brodmann I82I; Državni popisi prebivalstva I869-1910.

Tabela 6.2: Število in stopnja povprečne letne rasti prebivalstva kraškega dela tržaškega teritorija I648-1910 (v promilih)

\begin{tabular}{ccc}
\hline Leto & Prebivalcev & Letna stopnja rasti \\
\hline 1648 & 1.545 & \\
\hline 1700 & 1.540 & $-0,1$ \\
\hline 1750 & 2.351 & 8,5 \\
\hline 1778 & 2.775 & 5,9 \\
\hline 1800 & 3.073 & 4,6 \\
\hline 1810 & 3.564 & 14,8 \\
\hline 1818 & 4.083 & 17,0 \\
\hline 1846 & 6.452 & 16,3 \\
\hline 1869 & 7.284 & 5,3 \\
\hline 1880 & 7.680 & 4,8 \\
\hline 1890 & 7.950 & 3,5 \\
\hline 1900 & 8.158 & 2,6 \\
\hline 1910 & 9.375 & 13,9 \\
\hline
\end{tabular}


Razloge je treba iskati v razgibanih dogajanjih na koncu 18. stoletja. Od leta 1789 do 1800 je število umrlih v tržaški občini znatno presegalo število rojenih. Naravna bilanca je bila pozitivna samo v letih 1791 in 1799. Skupno je v tem obdobju umrlo $16 \%$ ljudi več, kot se jih je rodilo. Vrhunci smrtnosti so bili v letih 1794,1796 in predvsem leta 1800 , ko je število smrti za $50 \%$ presegalo število rojenih. To desetletje je bilo za Trst in njegovo ekonomijo zelo razgibano. $\mathrm{V}$ prvi polovici je mesto občutilo učinke vojne med Avstrijo in revolucionarno Francijo, v drugi pa francoske zasedbe. Na visoko umrljivost so vplivale predvsem črne koze, ki so se pojavljale skoraj vsako leto. Najmočneje so razsajale v letih 1789 , 1792, predvsem pa v letih 1796 in 1800 , ko je za boleznijo umrlo 485 oz. 439 oseb. Skupno je bolezen v obdobju 1789-1800 pobrala 1.404 življenj. Širila se je predvsem v mestu, $\mathrm{v}$ manjši meri pa je prizadela tudi okolico. Kljub visoki umrljivosti je prebivalstvo mesta od srede sedemdesetih let zaradi množičnega priseljevanja hitro naraščalo (po ocenah 25 promilov na leto). Tudi obračun naravne rasti je bil zaradi dotoka mladega prebivalstva $v$ reproduktivni starosti pozitiven (Breschi, Kalc in Navarra 2001, 95).

Kaj pa okolica? Za devetdeseta leta nimamo podatkov o rojstvih in smrtih za celotno kraško območje. Iz posameznih primerov vasi se vsekakor kaže, da umrljivost ni tako močno pogojevala naravne rasti prebivalstva kot v mestu. Število rojenih je v tem desetletju krepko preseglo število umrlih. Učinek naravnega prirastka na število prebivalstva pa je zmanjševalo izseljevanje. $V$ tej fazi je mesto poleg priseljencev iz širšega zaledja pritegnilo tudi okoliške prebivalce.

Tudi prvo dvajsetletje 19. stoletja je bilo za Trst in njegovo okolico zelo razgibano, in sicer zaradi mednarodnih političnih in vojnih dogajanj, ki so posredno in neposredno vplivala na gospodarske razmere in razvoj prostega pristanišča. Padec Beneške republike leta 1797 je okrepil pomorski in trgovski položaj Trsta. Mesto je pritegnilo številne poslovneže in drugo prebivalstvo iz bivših beneških ozemelj. Njegova rast pa je poznala tudi več zastojev, predvsem za časa tretje francoske zasedbe in Ilirskih provinc. Takrat je Trst izgubil status prostega pristanišča in pomorsko-trgovski promet je močno upadel zaradi kontinentalne in pomorske blokade. $\mathrm{V}$ zadnjih dveh letih francoskega obdobja je mesto z izselitvijo več kot tretjine prebivalstva doživelo pravi demografski kolaps (Kalc 2011). Po odhodu Francozov pa so se izseljenci vrnili in z njimi so prišli novi priseljenci. Na koncu tega obdobja je tako mesto vseeno beležilo močno demografsko rast, ki se je nadaljevala do srede stoletja (Breschi, Kalc in Navarra 2001, 95). 


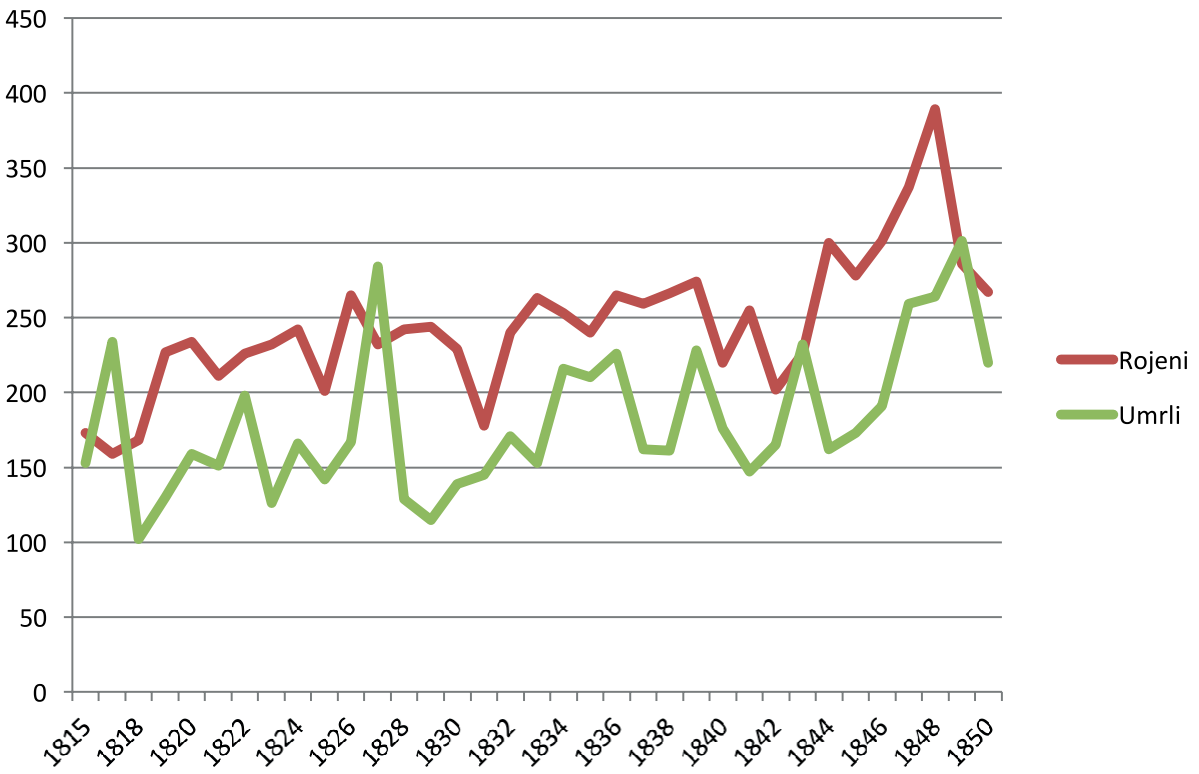

Graf 6.3: Rojstva in smrti vžupnijah Opčine, Prosek, Bazovica, Križ in Kontovel v letih i815I850 (absolutne vrednosti)

Vir: Montanelli 1905.

Tržaške kraške vasi so v prvi polovici 19. stoletjem doživele najhitrejšo rast prebivalstva celotnega obravnavanega obdobja. V prvih desetih letih je bila stopnja letne rasti nekoliko nižja od izkazane v tabeli $6.2(14,8$ promila), ker je podatek o prebivalstvu iz leta 1800 , kot rečeno, prenizek. Tempo rasti pa je bil v primerjavi s prejšnjim obdobjem trikrat večji in se je nato še stopnjeval. Spremembe oblasti in upravnega sistema, davščine in služnosti, ki so jih nalagali Francozi, vojne razmere in drugi dejavniki so se odražali tudi tu. Kmetje so morali s svojo vprežno živino služiti francoski vojski in za druge potrebe administracije. Pogosto so bili na poti ne samo v mesto in po ožjem teritoriju, ampak vse do Ljubljane, kar je oteževalo njihove običajne gospodarske dejavnosti. Vendar okolica za časa Ilirskih provinc ni utrpela množičnega izseljevanja. Po odhodu Francozov je splošno krizo spremljala povečana umrljivost. Ta je dosegla višek leta 1816 in predvsem 1817 ob drugi zaporedni slabi letini, ki je bila posledica nenavadnih vremenskih pojavov, povezanih $\mathrm{z}$ izbruhom vulkana Tambore leta 1815. Tega leta je na Tržaškem število smrti v primerjavi z letom 1816 naraslo za $76 \%$ (Brodmann, 102). Naravni prirastek na kraškem območju je bil vsekakor, 
$\mathrm{z}$ izjemo par let, $\mathrm{v}$ tem desetletju znatno pozitiven (graf 6.3). K rasti prebivalstva, ki je znašla povprečno 17 promilov, pa je v tej fazi prispevalo tudi priseljevanje.

Po letu 1818 se je rast nadaljevala s skoraj enakim tempom (16,3 promila) do srede štiridesetih let. Tudi v tem obdobju je bil naravni saldo znatno pozitiven, kljub momentom visoke umrljivosti, zlasti ob epidemijah. Smrtnost je krepko presegla rodnost samo leta 1827 in manj izrazito leta 1843 ter 1849 (graf 6.3). Kolera leta 1836 v okolici ni imela tako tragičnih posledic kot v mestu, kjer je terjala 1.700 življenj (Breschi, Kalc in Navarra 2001, 109). Število prebivalstva kraških vasi je med letoma 1818 in 1846 naraslo za skoraj $60 \%$, od začetka stoletja pa za $110 \%$.

$\mathrm{V}$ drugi polovici stoletja je bil razvoj še dalje pozitiven, a veliko počasnejši. Do štetja 1869 (podatki po vaseh za štetje leta 1857 niso na voljo) je prebivalstvo naraščalo za povprečno 5,3 promile letno, v naslednjih treh desetletjih pa je rast postopoma pojemala. Sedemdeseta leta sta zaznamovali splošna agrarna kriza in hkrati kriza mestne ekonomije. Rast se je ponovno razživela šele v prvem desetletju 20. stoletja, ko se je dvignila na 13,9 promilov. Ta nihanja so odraz splošnih razmer, predvsem pa razvoja mesta. $\mathrm{V}$ drugi polovici stoletja je razvojni potencial proste luke, ki je omogočila razcvet tržaškega pomorskega in trgovskega emporija, začel slabeti in kazati, da je ta model za nove čase in razmere neustrezen. Zaradi tega so leta 1891 prosto luko ukinili in mesto se je spremenilo v pretovorno pristanišče. Hkrati je država podprla razvoj industrije. To je privedlo do nove gospodarske ekspanzije in z njo do hitrejše demografske rasti (Breschi, Kalc in Navarra 2001, 161). Tej je ob naravnem prirastku spet botrovalo predvsem priseljevanje, ki je bilo v kriznih momentih manjše, ob prvih znakih gospodarskega razvoja pa se je vselej močno okrepilo. V prvem desetletju 20. stoletja se je prebivalstvo tržaške občine dvignilo za skoraj $28 \%$, s 180.000 na 230.000 .

\subsection{Primer Bazovice}

Opisani demografski razvoj v kraškem delu tržaškega občinskega ozemlja lahko dodatno analiziramo na primeru kaplanije Bazovica. Ta je poleg Bazovice obsegala še Gropado, Padriče in Lipico. Bazovska kaplanija je tvorila najvzhodnejši del tržaškega kraškega območja. Za čas od srede 17. stoletja do osemdesetih let 18. stoletja, ko je njeno ozemlje cerkvenoupravno spadalo pod župnijo Dolina oz. njen vikariat Gročano, bomo uporabili statistiko rojstev iz Montanellijeve zbirke krstnih podatkov (Montanelli 1905). 


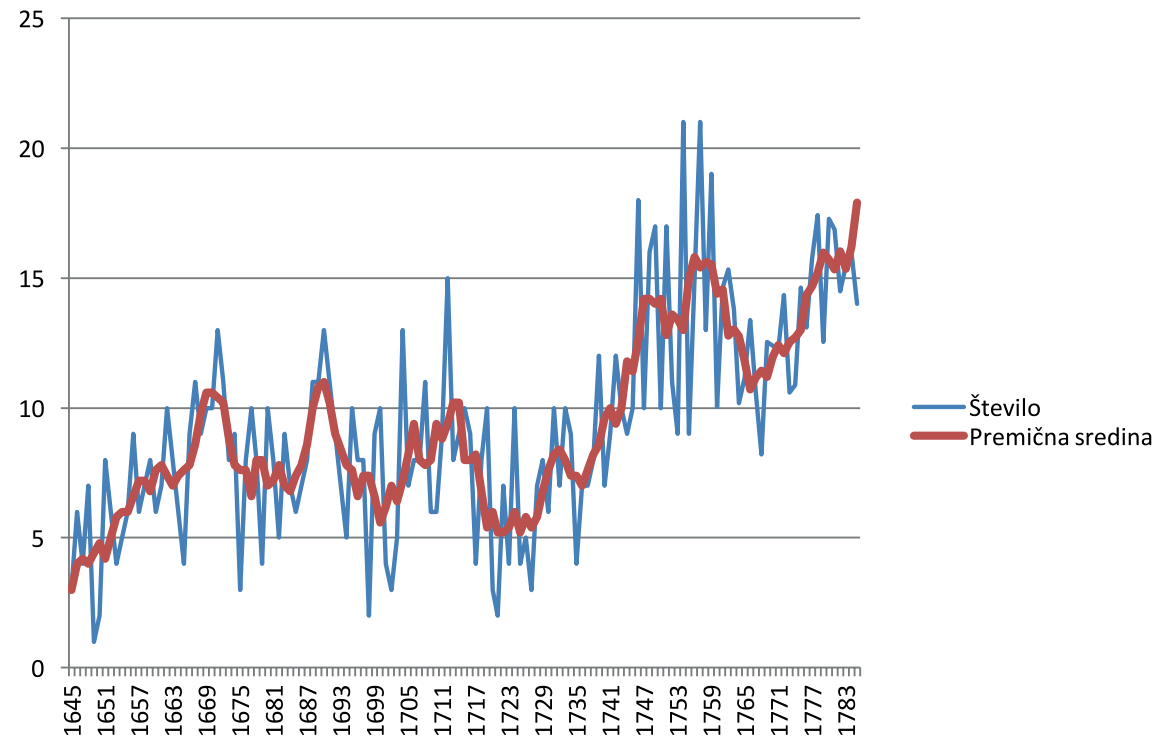

Graf 6.4: Rojstva v kaplaniji Bazovica v letih 1645-1800 (število in 5-letna premična sredina) Vir: ZAŽB, Knjige krstov in smrti.

Za čas od leta 1785 dalje, ko so jo ustanovili in ima svoje matrike, pa smo s pomočjo le-teh rekonstruirali statistiko rojstev in smrti. Razvoj števila prebivalstva vasi bazovske kaplanije se $\mathrm{v}$ glavnih obrisih sklada $\mathrm{z}$ razvojem teritorija, $z$ nekaterimi odstopanji in specifičnimi potezami.

Graf 6.4 ponazarja gibanje rojstev v bazovski kaplaniji od srede 17. do konca 18. stoletja. $\mathrm{V}$ tem primeru ni primerno ocenjevati števila prebivalstva na podlagi rojstev kot pri celotnem območju vasi, ker so številke premajhne. Dinamika rojstev na vsak način odraža glavne poteze in težnje razvoja. V drugi polovici 17. stoletja in do dvajsetih let 18 . so se zvrstili tri momenti naraščanja in upadanja rojstev, ki jim nedvomno odgovarja tudi nihanje števila prebivalstva. Obseg pa je bil na koncu obdobja po vsej verjetnosti samo malo večji od obsega na začetku obdobja, to je okrog 300 ljudi. Prebivalstvo je občutno naraslo v štiridesetih in petdesetih letih. Na podlagi razmerja med rojstvi in prebivalstvom ob konskripciji leta 1778 moremo oceniti, da ga je bilo sredi stoletja okrog 530. Sledilo depresivno obdobje, ki je sovpadalo s krizo $\mathrm{v}$ mestu, $\mathrm{v}$ sedemdesetih letih pa ponovna rast, ki se je nadaljevala do 1810 .

Proti koncu 18. stoletja je tudi v Bazovici število umrlih preseglo število rojenih, in sicer v letih 1789 in 1797 ob epidemijah črnih koz. V skup- 
nem seštevku pa je rodnost krepko presegala umrljivost, tako da je naravni letni prirast znašal 9,5 promilov. Kot na ostalem območju vasi pa je zaradi izseljevanja prebivalstvo naraščalo povprečno za 4,1 promila na leto.

\section{Tabela 6.3: Število in stopnje rasti prebivalstva v kaplaniji Bazovica v letih I648-1910}

\begin{tabular}{|c|c|c|c|c|c|c|}
\hline Leto & $\begin{array}{c}\text { Število } \\
\text { prebivalstva }\end{array}$ & $\begin{array}{c}\text { Dejanski } \\
\text { prirast }\end{array}$ & $\begin{array}{l}\text { Stopnja } \\
\text { rodnosti }\end{array}$ & $\begin{array}{c}\text { Stopnja } \\
\text { smrtnosti }\end{array}$ & $\begin{array}{c}\text { Naravni } \\
\text { prirast }\end{array}$ & $\begin{array}{l}\text { Selitveni } \\
\text { saldo }\end{array}$ \\
\hline & $\mathrm{a}$ & $\mathrm{b}$ & c & $\mathrm{d}$ & $e=c-d$ & $f=b-e$ \\
\hline 1648 & 300 & & & & & \\
\hline 1778 & 567 & 4,9 & & & & \\
\hline 1800 & 638 & 5,4 & 38,2 & 28,7 & 9,5 & $-4,1$ \\
\hline 1810 & 674 & 5,5 & 42,7 & 39,6 & 3,0 & 2,4 \\
\hline 1818 & 748 & 13,0 & 35,9 & 31,5 & 4,4 & 8,6 \\
\hline 1846 & 1.130 & 14,7 & 44,9 & 30,2 & 14,8 & $-0,2$ \\
\hline 1869 & 1.213 & 3,1 & 39,9 & 34,9 & 5,0 & $-1,9$ \\
\hline 1880 & 1.397 & 12,8 & 41,9 & 34,2 & 7,7 & 5,2 \\
\hline 1890 & 1.452 & 3,9 & 39,7 & 29,3 & 10,4 & $-6,5$ \\
\hline 1900 & 1.473 & 1,4 & 35,5 & 30,2 & 5,3 & $-3,9$ \\
\hline 1910 & 1.688 & 13,6 & 38,4 & 22,0 & 16,5 & $-2,8$ \\
\hline
\end{tabular}

V bazovski kaplaniji je prišlo do hitrejše rasti prebivalstva kasneje kot na ostalem tržaškem kraškem območju. Začela se je šele po letu 1810 in se nato okrepila po letu 1818. Do tega leta je $\mathrm{k}$ njej prispevalo priseljevanje, do srede stoletja pa znatno povečan naravni prirastek. Domnevati smemo, da je tudi v drugih vaseh, predvsem $v$ večjih, $k$ rasti $v$ prvem dvajsetletju vplivalo priseljevanje. Razlike med Bazovico in ostalim območjem opozarjajo na večji razvojni potencial nekaterih drugih vasi, ki so imele ugodnejši prometni položaj in tudi več priložnosti navezovanja na ekonomijo mesta.

V drugi polovici 19. stoletja se je razvoj prebivalstva $\mathrm{v}$ Bazovici spet razlikoval od ostalega kraškega območja. Medtem ko je bila rast v petdesetih in šestdesetih letih šibkejša, je močno izstopala v sedemdesetih letih. Najbrž je bilo to povezano $z$ dejstvom, da je vas leta 1872 postala upravno središče vzhodnega kraškega okraja tržaške občine in to ostala do leta 1885, ko so okrajni sedež premestili na Opčine. V vasi sta bila ta čas tudi okrajni zdravnik in načelnik. $40 \%$ rasti prebivalstva je v sedemdesetih letih prispevalo priseljevanje. $\mathrm{V}$ osemdesetih in devetdesetih letih je demografska rast 
skladno s splošno tendenco pešala. V novem stoletju se je spet razživela in se izenačila s povprečjem celotnega območja. Od osemdesetih let dalje je podobno kot med letoma 1818 in 1869 rast spodbujal naravni prirastek. Obe obdobji je spremljalo tudi izseljevanje, ki je nastopilo po obdobjih povečane naravne rasti in ob kriznih momentih, ki so očitno spremenili razmerja med prebivalstvom in gospodarskimi viri. Izseljevanje je bilo najmočnejše $\mathrm{v}$ osemdesetih letih. Njegova stopnja je nato padala, in to tudi na začetku novega stoletja, ko je bila naravna rast prebivalstva najmočnejša in je absolutna rast beležila enega izmed najizrazitejših momentov.

$\mathrm{V}$ 17. stoletju in še $\mathrm{v}$ prvih desetletjih 18 . je bila nataliteta $\mathrm{v}$ tržaški občini dokaj nizka. Raziskave jo skupaj za mesto in okolico ocenjujejo na okrog 32 promilov (Montanelli 1905, 29; Breschi, Kalc in Navarra 2001, 93). V kraških vaseh se je po naših ocenah gibala okrog 36 promilov. Po proglasitvi prostega pristanišča je začela naraščati: sredi 18. stoletja je znašala 38 promilov, ob konskripciji 1778 okrog 43 promilov, leta 1800 pa je presegla 50 promilov.

V Bazovici je bila nataliteta vseskozi nižja, saj je še ob popisu 1778 znašala manj kot 30 promilov, do konca 18. stoletja pa se je dvignila na 44 promilov. To odstopanje od povprečja je bilo delno odvisno od Lipice, kjer so živeli večinoma samski delavci, in od prisotnosti večje skupine stražnikov v Bazovici. Lipica je začela prispevati $\mathrm{k}$ rodnosti šele $\mathrm{v}$ osemdesetih letih 19. stoletja. Kot je razvidno iz tabele 6.3, se je v 19. stoletju rodnost v bazovski kaplaniji vrtela okrog 40 promilov. Šele v devetdesetih letih je začela upadati in kazati znake tranzicije. Tudi smrtnost je bila dokaj visoka, presegala je krepko 30 promilov in se v določenih obdobjih približala 40 promilom. Kot je tipično za režim starega reda, je šlo predvsem za otroško umrljivost, ki je na celotnem kraškem območju še sredi stoletja predstavljala več kot polovico celotne smrtnosti. V Bazovici je bilo v prvi polovici stoletja $32 \%$ vseh umrlih otrok mlajših od enega leta, $20 \%$ pa otrok od enega do petega leta starosti. ${ }^{3} \mathrm{~V}$ teku 19. stoletja je smrtnost beležila mnogo izrazitih konic, ki so v letih 1807, 1817, 1835, 1849, 1866, 1870 in 1894 znatno presegle število rojstev. Ti momenti, sovpadajoči z raznimi epidemijami, pa niso ogrozili sicer nihajočega pozitivnega naravnega trenda. Temu je botrovala predvsem visoka rodnost, saj je smrtnost tranzicijsko upadla šele na začetku 2o. stoletja.

3 Izračunanio na podlagi letnih poročil tržaških dušnopastirskih postaj, ki jih hrani Archivio Generale del Comune di Trieste, fond: Archivio Magistratuale, 1815-1852. 


\subsection{Prebivalstvo povirske prafare}

Gibanje in obseg prebivalstva povirske prafare do 19. stoletja moremo, ob pomanjkanju popisnih podatkov, od srede 17. stoletja $\mathrm{v}$ grobem oceniti na podlagi statistike rojstev. Pri tem smo se poslužili enakega količnika kot pri oceni kraškega dela tržaškega teritorija, to je razmerja enega rojstva na vsakih 27,59 prebivalcev. Iz urbarjev izvemo, da je bilo v 15. stoletju območje redko poseljeno. Prazne hube indikativno kažejo, da je prebivalstvo vsaj do začetka stoletja upadalo, do konca pa se nekoliko povečalo (Kos 1954). Večja rast je nastopila v obdobju do srede 17. stoletja, ko ocena izkaže približno 1.600 prebivalcev. V drugi polovici 17. stoletja je bila dinamika podobno kot $\mathrm{v}$ tržaških vaseh nihajoča in število prebivalcev se ni bistveno spremenilo. V 18. stoletju je opaziti tendenco naraščanja do kriznega momenta $\mathrm{v}$ štiridesetih letih in nato ponovno rast do sedemdesetih let. Dinamika je bila torej v glavnem enaka dinamiki tržaških vasi in Trsta.

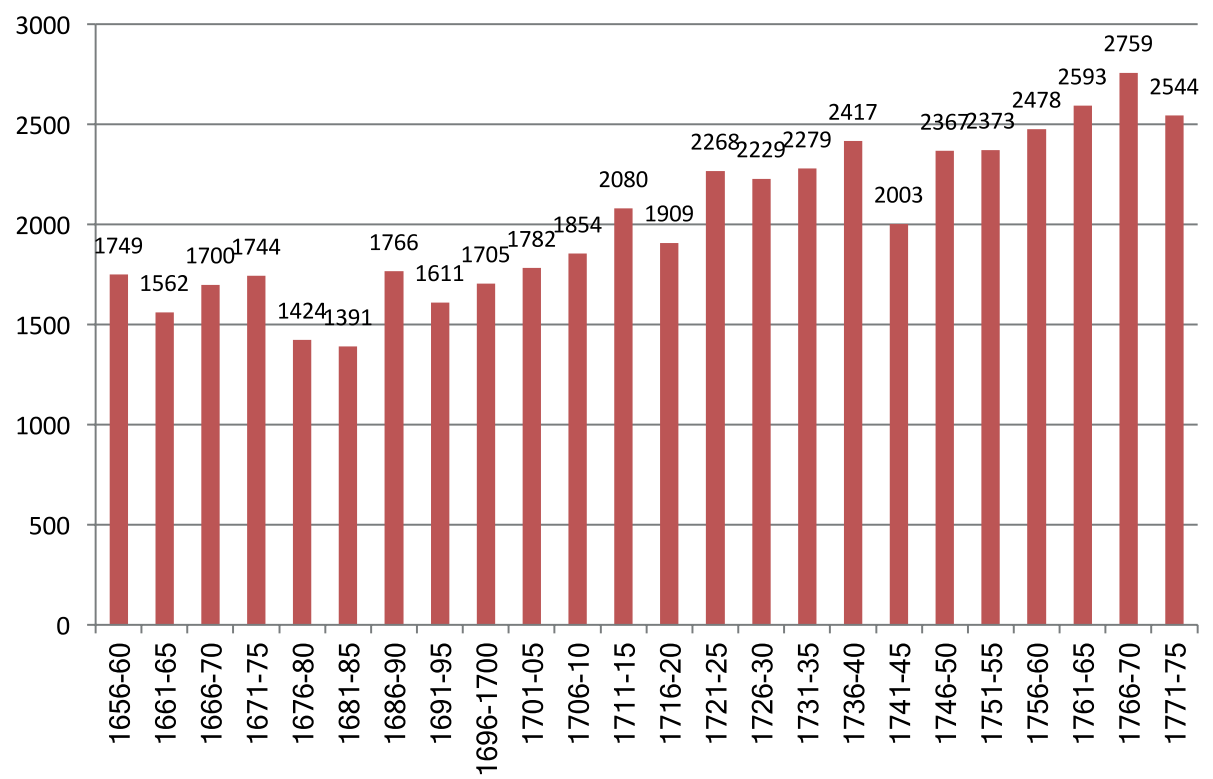

Graf 6.5: Ocena števila prebivalstva v povirski prafari na podlagi števila rojstev v letih 1656-1775

Vir: ŠAK, Župnija Povir, Župnija Sežana, Župnija Divača, Kaplanija Štorje, Knjige krstov. 


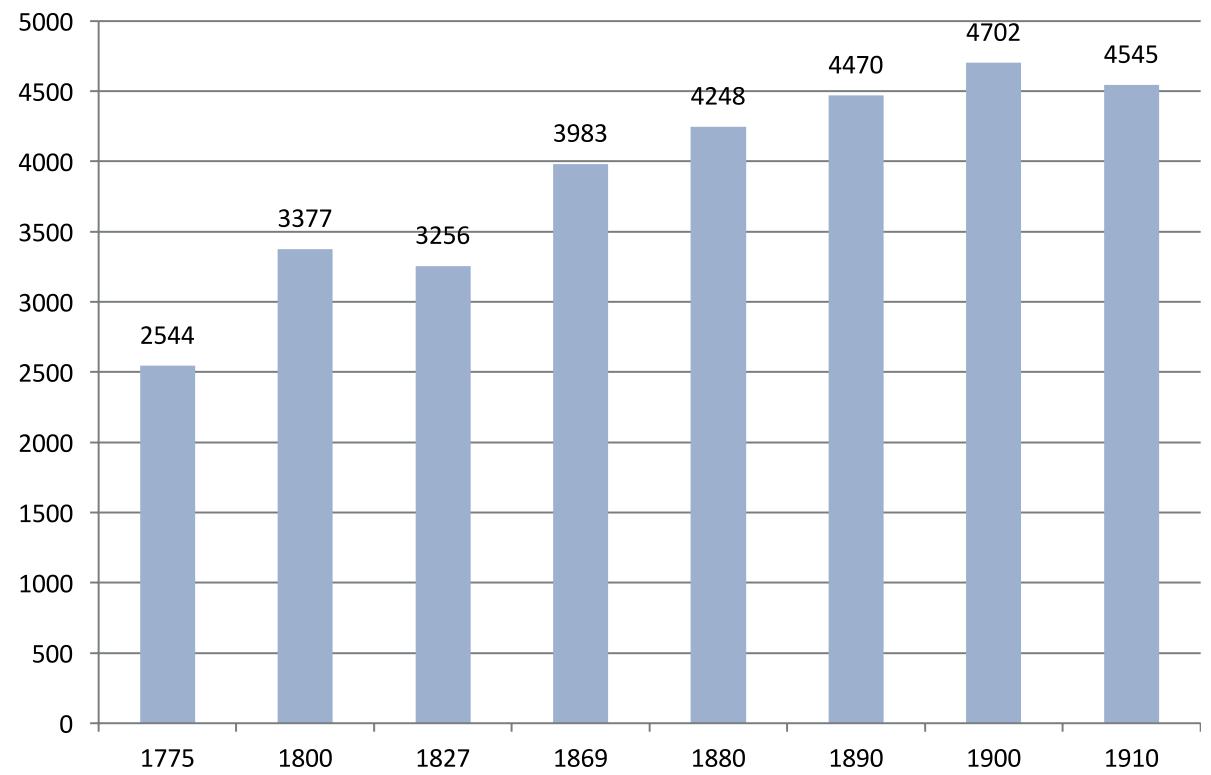

Graf 6.6: Razvoj števila prebivalstva na ozemlju povirske prafare v letih $1775-1910$ (1775 in I8oo ocene)

Vir: ŠAK, Župnija Povir, Župnija Sežana, Župnija Divača, Kaplanija Štorje, Knjige krstov; AST, CF. I827; Državni popisi prebivalstva I869-1910.

Tabela 6.4: Število in stopnja povprečne letne rasti prebivalstva na ozemlju povirske prafare v letih $1775^{-1910}$ (v promilih)

\begin{tabular}{|ccc|}
\hline Leto & Število prebivalcev & Letna stopnja rasti \\
\hline 1775 & 2.544 & 11,3 \\
\hline 1800 & 3.377 & $-1,4$ \\
\hline 1827 & 3.256 & 4,8 \\
\hline 1869 & 3.983 & 5,9 \\
\hline 1880 & 4.248 & 5,1 \\
\hline 1890 & 4.470 & 5,1 \\
\hline 1900 & 4.702 & $-3,4$ \\
\hline 1910 & 4.545 & \\
\hline
\end{tabular}

Od sedemdesetih let dalje pa so $\mathrm{v}$ razvoju povirskega in tržaškega kraškega prebivalstva vidne razlike. V zadnji četrtini 18 . stoletja je pre- 
bivalstvo povirskega območja naraščalo veliko hitreje, čemur je botrovalo tudi priseljevanje. Sodeč po rojstvih je bila rast posebno živahna v devetdesetih letih. Nato je bila do konca šestdesetih let 19. stoletja v primerjavi s tržaškim kraškim območjem zelo skromna. Medtem ko se je na Tržaškem v tem sedemdesetletnem obdobju število prebivalstva podvojilo, je na povirskem območju naraslo le za okrog $20 \%$. Posebno kritična so bila prva tri desetletja 19. stoletja, ko je število prebivalstva, kljub višji stopnji naravne letne rasti kot $\mathrm{v}$ devedesetih letih 18. stoletja (približno več kot 9 promilov), upadlo zaradi izseljevanja, katerega letno povprečje je znašalo 11 promilov. Izseljevanje (3,7 promila na leto) je pogojevalo tudi nadaljnji razvoj do konca šestdesetih let, $v$ teku katerega se je stopnja naravne letne rasti znižala na 8,5 promila. Mortaliteta je le izjemoma presegala nataliteto, najizraziteje na začetku stoletja in $\mathrm{v}$ petdesetih letih, ko je razsajala kolera. V zadnjih tridesetih letih 19. stoletja je število prebivalstva naraščalo hitreje kot na Tržaškem in dokaj enakomerno, v prvem desetletju 2o. stoletja pa je nazadovalo, medtem ko se je v tržaških kraških vaseh znatno povečalo. V obdobju 1870-1910 se je število prebivalcev kraškega dela tržaškega teritorija povečalo za $29 \%$, na ozemlju povirske prafare pa za $14 \%$. Razlika je še očitnejša, če primerjamo obdobje med letoma 1818 oz. 1827 in 1910: prebivalstvo tržaških kraških vasi je naraslo za 130 \%, v vaseh povirske prafare pa za $40 \%$.

Tabela 6.5: Dejanski in naravni prirast ter selitveni saldo v okrajnem glavarstvu Sežana v letih $1870-1910^{4}$

\begin{tabular}{cccc}
\hline Leta & Dejanski prirast & Naravni prirast & Selitveni saldo \\
\hline $1870-80$ & 0,1 & 9,1 & $-9,0$ \\
$1880-90$ & 4,2 & 9,8 & $-5,7$ \\
\hline $1890-00$ & 2,8 & 10,9 & $-8,1$ \\
\hline $1900-10$ & 4,7 & 14,2 & $-9,4$ \\
\hline $1870-1910$ & 12,2 & 45,5 & $-33,3$ \\
\hline
\end{tabular}

Vir: glej opombo 4 .

4 Österreichische Statistik (1882-1914): Ergebnisse der Volkszählungen etc., Band I, Heft 1 (1880); Band XXXII, Heft 1, 2, 5(1890); Band LXIII, Heft 1, 2; Band LXIV, Heft 1, 2(1900); Band 1 Neue Folge, Heft 1, 2; Band 2 Neue Folge, Heft 1(1910). Wien, K.k. Statistische Central-Commission. 
Ker za zadnjih 30 let 19. stoletja nimamo statistike o naravnem gibanju, ne moremo izračunati stopenj naravne rasti in selitvenega salda. $\mathrm{O}$ splošnih tendencah demografskega dogajanja pa jasno govorijo podatki za ozemlje okrajnega glavarstva Sežana, prikazani v tabeli 6.5. Za to območje, ki je vključevalo večji del tržaškega kraškega zaledja, je bila značilna zelo skromna rast prebivalstva zaradi izseljevanja, ki je bilo usmerjeno predvsem v Trst. V osemdesetih letih je pasivna migracijska bilanca znašala 58 $\%$ naravnega prirasta, v naslednjih dveh desetletjih pa 75 oz. $73 \%$ (Kalc 2013, 691). V deželi Goriško-Gradiški je imelo okrajno glavarstvo Sežana najvišji pasivni migracijski saldo in v prvem desetletju 2o. stoletja, ko se je tudi na hribovitem Tolminskem po dolgem upadanju obrnila v pozitivno smer, najnižjo rast števila prebivalstva.

\section{Tabela 6.6: Prebivalstvo in stopnje letne rasti v katastrski občini Sežana v letih I827-1910}

\begin{tabular}{|c|c|c|c|c|c|c|}
\hline & $\begin{array}{c}\text { Število } \\
\text { prebivalcev }\end{array}$ & $\begin{array}{c}\text { Absolutni } \\
\text { prirast }\end{array}$ & $\begin{array}{l}\text { Letna } \\
\text { stopnja } \\
\text { rodnosti }\end{array}$ & $\begin{array}{c}\text { Letna } \\
\text { stopnja } \\
\text { umrljivosti }\end{array}$ & $\begin{array}{c}\text { Letni } \\
\text { naravni } \\
\text { prirast }\end{array}$ & $\begin{array}{c}\text { Letni } \\
\text { selitveni } \\
\text { prirast }\end{array}$ \\
\hline 1827 & 1.008 & & & & & \\
\hline 1869 & 1.663 & 11,9 & 43,7 & 31,9 & 11,7 & 0,0 \\
\hline 1880 & 1.792 & 6,8 & 39,9 & 33,3 & 6,6 & 0,2 \\
\hline 1890 & 1.779 & $-0,7$ & 37,5 & 32,4 & 5,1 & $-5,8$ \\
\hline 1900 & 1.876 & 5,3 & 37,8 & 28,4 & 9,4 & $-4,0$ \\
\hline 1910 & 1.821 & $-3,0$ & 37,3 & 23,3 & 14,1 & $-17,0$ \\
\hline
\end{tabular}

Podrobneje lahko o dejavnikih razvoja spregovorimo za katastrsko občino Sežana, ki je obsegala vasi Sežana, Dane, Orlek in Šmarje (tabela 6.6). Razvoj Sežane se je nekoliko razlikoval tako znotraj okrajnega glavarstva kot tudi območja povirske prafare. Med letoma 1827 in 1910 se je prebivalstvo sežanske katastrske občine povečalo za $80 \%$, prebivalstvo ozemlja povirske prafare pa za $40 \%$. Razlika je nastala predvsem v predmarčni dobi in do konca šestdesetih let, ko je kljub izseljevanju število prebivalstva v sežanski katastrski občini živahneje naraščalo. Rast se je nadaljevala $\mathrm{v}$ sedemdesetih letih in nato $\mathrm{v}$ devetdesetih letih, medtem ko je $\mathrm{v}$ osemdesetih in v prvem desetletju 20. stoletja število prebivalcev nazadovalo in to kljub padcu umrljivosti. Kot na ostalem ozemlju okrajnega glavarstva, tako je tudi tu rast omejevalo izseljevanje, ki je v osemdesetih letih in predvsem na začetku novega stoletja povzročilo upad števila prebivalstva. Za razliko od ostalega ozemlja sežanskega okrajnega glavarstva, kjer je izsel- 
jevanje zaznamovalo obdobje od sedemdesetih let 19. stoletja dalje, se je v katastrski občini Sežana v tej zgodovinski fazi pojavilo v osemdesetih letih in se močno razživelo $\mathrm{v} 2 \mathrm{O}$. stoletju.

Tabela 6.7: Število in indeks rasti $(1869=$ 100) prebivalstva na ozemlju povirske prafare po katastrskih občinah

\begin{tabular}{|c|c|c|c|c|c|c|c|c|c|c|c|c|}
\hline \multirow[b]{2}{*}{ Leto } & \multicolumn{2}{|c|}{ Povir } & \multicolumn{2}{|c|}{ Merče } & \multicolumn{2}{|c|}{ Štorje } & \multicolumn{2}{|c|}{ Divača } & \multicolumn{2}{|c|}{ Ležeče } & \multicolumn{2}{|c|}{ Sežana } \\
\hline & Preb. & Indeks & Preb. & Indeks & Preb. & Indeks & Preb. & Indeks & Preb. & Indeks & Preb. & Indeks \\
\hline 1827 & 743 & 100 & 454 & 100 & 555 & 100 & 244 & 100 & 252 & 100 & 1.008 & 100 \\
\hline 1869 & 754 & 101 & 465 & 102 & 589 & 106 & 215 & 88 & 297 & 118 & 1.663 & 165 \\
\hline 1880 & 727 & 98 & 483 & 106 & 550 & 99 & 374 & 153 & 322 & 128 & 1.792 & 178 \\
\hline 1890 & 736 & 99 & 498 & 110 & 574 & 103 & 550 & 225 & 333 & 132 & 1.779 & 176 \\
\hline 1900 & 762 & 103 & 486 & 107 & 613 & 110 & 644 & 264 & 321 & 127 & 1.876 & 186 \\
\hline 1910 & 779 & 105 & 483 & 106 & 537 & 97 & 594 & 243 & 331 & 131 & 1.821 & 181 \\
\hline
\end{tabular}

Vir: AST, CF I827; Državni popisi prebivalstva 1869-1910.

$\mathrm{V}$ razvoju vasi povirske prafare prihaja do izraza dvoje tendenc. V Povirju, Merčah in Štorjah se število prebivalstva od dvajsetih let do prve svetovne vojne ni bistveno spremenilo. Tudi naselja se niso bistveno povečala, saj je v Povirju število hiš naraslo za 27 \%, v Merčah za 19 \% in v Štorjah za $11 \%$. Večina novih hiš je bila zgrajenih do konca šestdesetih let. Nekoliko konsistentnejša je bila rast prebivalstva $v$ katastrski občini Ležeče, izrazitejša pa v Sežani in še veliko bolj v Divači. V slednjih dveh je število hiš naraslo za 92 oz. 89 \%. Rast teh dveh občin je bila povezana z njuno upravno, trgovsko oz. prometno vlogo in botrovala ji je v glavnem rast vasi Sežane in Divače, medtem ko je $\mathrm{v}$ drugih naseljih, razen izjem, ostajalo število prebivalstva in hiš skoraj nespremenjeno. Sežana se je kot že omenjeno razvila do sedemdesetih let, za razliko je Divača rasla v zadnjih tridesetih letih 19. stoletja. V obeh primerih je na začetku 20. stoletja prebivalstvo upadlo zaradi izseljevanja, ki je sicer pogojevalo gibanje števila prebivalstva $\mathrm{v} v$ seh katastrskih občinah. 


\section{Vplivi in učinki razvoja Trsta}

Če se vrnemo $k$ tržaškemu teritoriju in splošnim potezam razvoja kraškega dela, opazimo v dolgem obdobju razne faze. V 125 letih do srede 17. stoletja je prebivalstvo kljub občasnim zastojem hitro naraščalo, saj moremo povprečno letno rast oceniti na dobrih 9 promilov. Domnevati smemo, da je bilo dejansko gibanje zelo nihajoče, da je k rasti prispevalo priseljevanje kmečkih družin s slovenskega zaledja in drugih območij. Sklepati smemo tudi, da je bila rast najbolj poudarjena $\mathrm{v}$ prvi polovici 17. stoletja, zlasti potem, ko so se pomirile strasti z Benetkami in je zavladalo daljše obdobje miru. Druga polovica 17. stoletja je bila spet razgibana, vendar je na koncu obdobja bilanca rasti ostala bolj ali manj nespremenjena. Novo obdobje rasti se je začelo $\mathrm{v}$ 18. stoletju, ko je Trst dobil status prostega pristanišča in zaživel kot pomorsko ter trgovsko središče. Pravni režim prostega pristanišča je veljal v celotni občini, tako da je brezcarinske in druge privilegije (vključno z oprostitvijo vojaške službe) uživala tudi kmečka okolica. Novi demografski trendi se v drugi polovici stoletja kažejo predvsem v stopnjevanju rodnosti. Ta prevladuje nad sicer visoko in mestoma presežno smrtnostjo in spodbuja rast števila prebivalstva. Vendar so učinki pospešene naravne rasti delni, ker jih zlasti proti koncu stoletja zmanjšuje izseljevanje.

Posledice ugodnega razmerja med rodnostjo in smrtnostjo se jasneje kažejo $\mathrm{v}$ rasti prebivalstva $\mathrm{v}$ prvi polovici 19. stoletja. To je obdobje najhitrejše demografske rasti $v$ celem slovenskem prostoru in zlasti na njegovem zahodnem delu. V kraških vaseh na Tržaškem tej živahni rasti v prvih desetletjih botruje spet priseljevanje, nato pa jo pogojuje izseljevanje, ki je značilno, z izjemo sedemdesetih let, vse do prve svetovne vojne. Rast prebivalstva se $\mathrm{v}$ prvih dveh desetletjih 19. stoletja odraža v povečanju družin, na katere pride leta 1800 (kot tudi 1778) 5,1 člana, leta 1818 pa 5,6 člana. Do konca 19. stoletja se prebivalstvo tržaških kraških vasi razvija na podlagi demografije starega reda $\mathrm{z}$ značilno visokimi stopnjami rodnosti in smrtnosti. Naravno gibanje je $\mathrm{v}$ dolgem obdobju, kljub pogostemu poskakovanju in presežkom smrtnosti, pozitivno, kar prispeva $\mathrm{k}$ stalnemu naraščanju števila prebivalstva. Demografska tranzicija se pojavi v prvem desetletju 20. stoletja $\mathrm{z}$ močnim upadom smrtnosti, medtem ko se rodnost še naprej ohranja na predmodernih nivojih. 
Tabela 6.8: Distribucija prebivalstva (a) in letne stopnje rasti (b) v kraškem delu tržaške občine v letih $1648-1910$

a)

\begin{tabular}{|c|c|c|c|c|}
\hline Leto & Zahodno območje & Srednje območje & Vzhodno območje & Skupno \\
\hline 1648 & 60,5 & 16,8 & 22,7 & 100,0 \\
\hline 1778 & 46,7 & 27,2 & 26,1 & 100,0 \\
\hline 1800 & 44,8 & 28,8 & 26,4 & 100,0 \\
\hline 1810 & 45,7 & 28,9 & 25,4 & 100,0 \\
\hline 1818 & 45,8 & 30,4 & 23,8 & 100,0 \\
\hline 1846 & 43,6 & 31,4 & 25,0 & 100,0 \\
\hline 1869 & 44,1 & 31,2 & 24,7 & 100,0 \\
\hline 1880 & 44,3 & 29,9 & 25,7 & 100,0 \\
\hline 1890 & 44,5 & 29,8 & 25,7 & 100,0 \\
\hline 1900 & 44,9 & 29,1 & 26,0 & 100,0 \\
\hline 1910 & 41,9 & 32,0 & 26,0 & 100,0 \\
\hline
\end{tabular}

b)

\begin{tabular}{lcccc} 
Leto & Zahodno območje & Srednje območje & Vzhodno območje & Skupno \\
\hline 1648 & 9,2 & & & \\
\hline 1778 & 2,5 & 8,2 & 5,6 & 4,5 \\
\hline 1800 & 2,7 & 7,3 & 5,2 & 4,6 \\
\hline 1810 & 16,8 & 15,3 & 10,8 & 14,8 \\
\hline 1818 & 17,4 & 23,2 & 8,8 & 17,0 \\
\hline 1846 & 14,6 & 17,5 & 18,1 & 16,3 \\
\hline 1869 & 5,8 & 4,9 & 4,8 & 5,3 \\
\hline 1880 & 5,3 & 1,2 & 8,4 & 4,8 \\
\hline 1890 & 3,8 & 3,0 & 3,4 & 3,5 \\
\hline 1900 & 3,6 & 0,0 & 3,8 & 2,6 \\
\hline 1910 & 7,0 & 23,7 & 14,0 & 13,9 \\
\hline
\end{tabular}

Demografski razvoj tržaških kraških vasi je sledil splošnim trendom demografskega razvoja, hkrati pa je bil povezan $\mathrm{z}$ razvojem Trsta. To pride še bolj do izraza od podelitve statusa prostega pristanišča v 18. stoletju. Od takrat je na območju vasi tržaške okolice opaziti spremembo v distribu- 
ciji prebivalstva. Kot omenjeno, je bila v starejših obdobjih poselitev koncentrirana v zahodnih naseljih kraškega območja. Še sredi 17. stoletja, ko se je v srednjem in vzhodnem delu število prebivalcev že povečalo, jih je 60 \% živelo v Križu, na Kontovelu in Proseku. V drugi polovici 18. stoletja pa se je delež srednjega in vzhodnega območja dvignil na 55 \% (tabeli $6.8 \mathrm{a}$ in $6.8 \mathrm{~b})$.

Sprememba v drugi polovici 18. stoletja je bila strukturne narave. Prebivalstvo kraških vasi je bilo, kot rečeno, večinoma kmečko in kmetijstvo se je ohranilo kot primarna gospodarska dejavnost $\mathrm{v}$ celotnem obravnavanem časovnem loku. Kmetje so bili večinoma mali posestniki in gospodarili so večinoma s pomočjo rodbinske delovne sile. Le nekoliko premožnejše družine so imele enega in redkeje po več poslov (leta 177813 $\%$ družin) (Kalc 2009). Agrarna struktura pa se je razlikovala po kulturah. Zahodne vasi so, kot rečeno, razpolagale z zemljišči na flišnatem bregu pod kraškim robom, kjer je stoletja potekalo intenzivno gojenje vinske trte. To je omogočalo razmeroma živahno tržno ekonomijo, tudi zaradi tega, ker je bilo to vino boljše kvalitete in so ga oddajali tako v mesto kot odjemalcem izven tržaškega ozemlja. V tržaški občini je med drugim veljal vinski protekcionizem. Zaradi večjih proizvajalnih stroškov, povezanih z vzdrževanjem vinogradov na strmih legah, naraščanja cene agrarnega mezdnega dela in splošnega varovanja interesov tržaške agrarne ekonomije pred konkurenco furlanskih in istrskih živilskih proizvodov je v mestu tržaško vino za konzum uživalo prednostno prodajno pravico. Trajanje vsakoletnega prednostnega obdobja, ko so v gostilnah smeli točiti samo tržaško vino, je bilo odvisno od tržaške vinske letine in povpraševanja (Kalc 2005). Tri zahodne kraške vasi so imele tudi ugoden prometni položaj ob cesti proti Beneški republiki. V Križu in na Kontovelu se je del prebivalstva ukvarjal še z ribištvom (Volpi Lisjak 1995).

V srednjem in vzhodnem delu kraškega območja niso proizvajali višje cenjenih tržnih pridelkov. Ponekod so imeli manjša vinogradniška območja in nekateri kmetje so najemali zemljičča na vinorodnih legah pod kraškim robom. V glavnem pa je bil svet kraški in agrarna ekonomija je temeljila na poljščinah ter na živinoreji. V starejših obdobjih so se ukvarjali predvsem $\mathrm{z}$ ovčerejo, $\mathrm{v}$ modernejših pa $\mathrm{z}$ govedorejo. Bližina mesta je vsekakor tudi $v$ teh vaseh omogočala nekaj prodaje in zaslužka od dopolnilnih dejavnosti. Hitrejšo rast in spremembo $\mathrm{v}$ distribuciji prebivalstva $\mathrm{v}$ drugi polovici 18. stoletja moremo vzporejati s povečanim mestnim povpraševanjem po prehrambenih pridelkih in povečanimi možnostmi za 
neagrarne dejavnosti (Kandler 1846; Dorsi 1989; Kalc 20o9; Panjek 2015, 90, 101-2).

$Z$ rastjo pristanišča se je okrepila prometna vloga srednjega in vzhodnega kraškega območja, predvsem pa Opčin in Bazovice. Mimo Bazovice je vodila cestna povezava med Trstom in Reko, ki so jo zgradili v šestdesetih letih 18. stoletja. Tržaška občina je zato v Bazovici postavila gostilno s počivališčem za voznike in vprežno živino. Tu sta bili še carinarnica in postaja mejnih stražarjev, sredi osemdesetih let je postala vas sedež samostojne kaplanije, proti koncu stoletja pa so odprli šolo. Bazovica je razpolagala $z$ obsežnim vaškim ozemljem, na katerem so kmetje pridobivali nove obdelovalne površine in travnike, velike pa so bile tudi pašniške in druge površine v skupni rabi. Še bolj so se okrepile prometna vloga in z njo povezane gospodarske dejavnosti na Opčinah. Skozi Opčine je tekla cestna povezava Trsta $s$ Kranjsko in $z$ vzhodnejšimi ter s severnejšimi avstrijskimi deželami. Ta se je ob vasi križala s cesto, ki je vodila v eni smeri proti Reki, v drugi proti Furlaniji. Ko so leta 1780 dogradili neposredni cestni odsek, ki je skrajšal pot z Opčin v spodnje mesto, se je ponudila nova možnost zaslužka: podpora vozovom pri premagovanju strmine, ki je terjala dodatno vprego desetih in več volov. Ta dejavnost je openskim in sosednjim kmetom prinašala zaslužek, dokler niso leta 1830 zgradili nove, položnejše cestne povezave med mestom in kraško planoto (Zubini 2007) .

Ekspanzija mesta je ponujala še druge vire neagrarnega zaslužka, na primer prevozne usluge $\mathrm{v}$ pristanišču in za potrebe vojske, delo $\mathrm{v}$ gradbenem sektorju in pri vzdrževanju javne infrastrukture. Vzdrževanje cest je spadalo med robotne obveznosti tržaških kmetov, ki so po opravljeni roboti delo nadaljevali proti plačilu. Nekateri so jemali vzdrževalna dela $\mathrm{v}$ zakup in pri njih zaposlovali sovaščane. Najbolj znana sta primera kmečkih in gostilničarskih družin Dolenc in Luxa s Proseka, ki sta v devetdesetih letih 18. stoletja tekmovali za tovrstni apalt. Posebno podjeten je bil dolgoletni proseški župan in vplivnež Matija Dolenc, ki je za opravljanje svojih robotnih obveznosti najemal revne sovaščane, dokler ga ni policijska direkcija prisilila k disciplini, ki je predvidevala neposredno opravljanje robotne dolžnosti. Bil pa je tudi poštni mojster v Sežani in Križu. Tu je na lastne stroške ob poštni postaji zgradil velik vodnjak za potrebe poštnih vpreg. Od kolektivnih gospodarskih pobud je zanimiv primer skupine kmetov iz Opčin, ki so v devetdesetih letih 18. stoletja vzeli v apalt tamkajšnjo občinsko gostilno s prenočišči in počivališči za furmansko živino, na območju sosesk pod kraškim robom pa primer apalta za vzdrževanje mestne čistoče. 
Ta občinski apalt je bil dolgo v domeni Ivana Marije Merlaka iz Škednja, dokler ga ni na začetku devetdesetih let odkupila skupnost kmečkih posestnikov iz soseske Svete Marije Magdalene Spodnje. Vendar se mu je morala v kratkem odpovedati, ker dela ni bilo mogoče uskladiti z delom na kmetijah. Problem je bila razdalja do mesta, kjer so morali vsak dan počistiti iztrebke vprežne živine in drugo nesnago, ki so jo potem prodajali drugim kmetom. K neagrarnim dejavnostim so okoliške kmete spodbujale same oblasti, ki so skrbele, da bi ob slabih kmečkih letinah ne občutili pomanjkanja ali padli v revščino. Zato so imeli pri najemanju delovne sile za opravljanje javno koristnih gradbenih del v občini prednost tržaški okoliški kmetje. V obdobjih hujšega pomanjkanja so jim oblasti priskočile na pomoč celo z namenskimi javnimi deli (Kalc 1999, 283-4; Kalc 2009, 75-6). V 19. stoletju, ko so se javne in zasebne gradnje še pospešile, so se okoliški kmetje ukvarjali s pripravljanjem, prevažanjem in prodajanjem gradbenega materiala in z vrsto drugih dejavnosti (Panjek 2015; Bufon in Kalc 1991).

Ekspanzija mesta in hitra rast prebivalstva sta $\mathrm{v}$ 19. stoletju spodbudili spremembe tudi v agrarni ekonomiji. Neposredna mestna okolica pod kraškim robom se je ob vinogradništvu specializirala za proizvodnjo zelenjave. Kraške vasi pa so se vse intenzivneje usmerile v govedorejo in mlekarstvo, medtem ko je ovčereja, ki je bila še na začetku 19. stoletja zelo razširjena, postopoma izginila. Govedoreja je bila gospodarsko posebno pomembna na vzhodnem delu kraškega območja, kjer je predstavljala primarno agrarno dejavnost. Na zahodnem delu se je zaradi ugodne klime ob vinogradništvu in mlekarski govedoreji kot posebna niša razvilo cvetličarstvo (Bufon in Kalc 1991). Tako pri mlekarstvu kot pri cvetličarstvu je imelo vidno vlogo žensko prebivalstvo, saj je bila prodaja mleka in cvetja v mestu skoraj izključno v domeni žensk.

Zahodne tržaške vasi so imele vseskozi bolj artikulirano ekonomijo in v teku 19. stoletja se je ta raznolikost še povečala. Na Kontovelu in v Križu je ribištvo dobivalo vse večji pomen in se iz pretežno dopolnilne spremenilo v primarno dejavnost. Ribištvo je bilo po eni strani rezultat modernizacije in prilagajanja gospodarskim priložnostim, po drugi sad razslojevanja kmečke skupnosti. Sami ribiči so bili razslojena družbena kategorija. Sestavljali so jo lastniki bark, med katerimi so se nekateri povzpeli na podjetniško raven in posedovali večje in tudi po več bark, in ribiški delavci, ki so sodili med proletariat. Ta proces se je $\mathrm{v}$ drugi polovici stoletja izražal tudi v vaški arhitekturi z diferenciacijo med kmečkimi hišami in bivališči ribičev, ki so bila manjša in brez gospodarskih poslopij (Semerani, De Rosa in Celli 
1970). Posebna vrsta lova je bil tunolov, ki je terjal kolektivno udeležbo vseh ribičev in pomoč širše vaške skupnosti za potegnitev polnih mrež na kopno. V drugi polovici 19. stoletja so se širili tudi mornariški in drugi poklici, povezani z morjem (Volpi Lisjak 1996). V Križu se je hkrati uveljavilo kamnarstvo, ki so ga spodbudile mestne in infrastrukturne gradnje kot na primer železniška, in sama rast vasi, v katerih se je z življenjskim standardom dvigovala tudi gradbena raven bivališč (Brecelj, Legiša in Vogrič 1989).

Zaradi diverzificirane ekonomije je bil Križv 19. stoletju najobljudenejša vas kraškega dela tržaške občine. Potem so prvo mesto prevzele Opčine, ki so prometno vlogo okrepile s postajo in oskrbovalno točko južne železnice, medtem ko se je konec 19. stoletja okrog zgodovinskega vaškega jedra začela širiti povsem nova soseska s številnimi razkošnimi meščanskimi vilami. K gospodarski in rezidenčni vlogi Opčin je prispevala tramvajska proga številka 2, ki so jo predali prometu leta 1903. Ta proga, imenovana »openski tramvaj«, je povezala kraški rob neposredno z mestnim središčem in s tem pospešila raznolikost openskega gospodarstva (Bufon in Kalc 1991). Manjše vasi, kot so bile Gropada, Padriče, Bani in Trebče, pa so ohranjale pretežno kmečki značaj in dohodek prebivalstva je temeljil na kombinaciji agrarnih dejavnosti ter zaslužka od dela v mestu.

\section{Podobnosti in razlike na povirskem območju}

Kot smo videli, se je od konca 18. stoletja demografski razvoj na območju povirske prafare razlikoval od razvoja kraških vasi tržaške občine. V zadnjem dvajsetletju 18. stoletja je povirsko prebivalstvo naraščalo hitreje od tržaškega, v 19. stoletju in do prve svetovne vojne pa se je težnja obrnila. Rast prebivalstva tržaških vasi je bila trikrat večja kot $\mathrm{v}$ povirski prafari. Razliko je v glavnem pripisati izseljevanju, ki je bilo na povirskem, od mesta nekoliko oddaljenejšem območju večje kot na tržaškem. Prebivalstvo je občutneje naraslo le v nekaterih vaseh, predvsem v Sežani in Divači. Tudi v pomembnem regionalnem središču, kot je bila Sežana, pa je ostajala rast od sedemdesetih let stoletja skromna in znatno nižja od rasti celotnega povirskega ozemlja. Prebivalstvo sežanske katastrske občine se je do zadnjega avstrijskega štetja leta 1910 povečalo le za $9 \%$ nasproti 14-odstotni rasti celotnega območja in 12-odstotni rasti na ozemlju sežanskega okrajnega glavarstva. Iz sežanske katastrske občine, ki se je nahajala v najugodnejši prometni legi do Trsta, je bil očitno odliv prebivalstva izrazitejši. Podobno tendenco kažeta zlasti na začetku 2o. stoletja tudi Štorje in Divača. 
Povirsko območje je bilo, podobno kot območje tržaških kraških vasi, zakoreninjeno $\mathrm{v}$ agrarni ekonomiji in tradicionalno povezano s Trstom. Povezano pa je bilo tudi z drugimi območji, ki so ponujala tržne možnosti kmetijstvu in hkrati priložnosti za neagrarne dejavnosti ter vire dohod$\mathrm{ka}$. Te različne gospodarske možnosti, povezane $\mathrm{v}$ integriran gospodarski sistem, je prebivalstvo izkoriščalo že v novem veku, v 18. in zlasti v 19. stoletju pa so se znatno razširile. Kmetje so mesto oskrbovali z mlekom, s poljskimi in z drugimi pridelki, kot so češnje in orehi, trgovali so z živino za zakol. Med odjemalci je bila od srede 19. stoletja tudi avstrijska vojaška mornarica. Že iz časov Beneške republike so imeli pomemben del dohodka od prodaje hrastovega in orehovega lesa za ladjarstvo, gradbeništvo in izdelavo pohištva. $S$ tem je bilo povezano tesarsko delo za grobo obdelavo hlodovine in njeno prevažanje. Med neagrarnimi viri dohodka sta bila shranjevanje in prodajanje ledu za potrebe mestnih živilskih obratov in ladij ter kamnoseštvo. Med domačimi obrtmi je, na primer, v Povirju našlo pot do trga tudi izdelovanje vrvi iz konoplje za potrebe ladjarstva. V krajih ob trgovskih poteh in skozi katere je bila speljana železnica, pa je bilo razvito gostilničarstvo in druge usluge, povezane s prometom. $\mathrm{V}$ zadnjih desetletjih 19. stoletja je območje postalo tudi letovišče in v Sežani je gostinski zaslužek prinašalo več hotelov (Pahor 1976; Skrinjar 2006) .

Krajevne agrarne in neagrarne gospodarske dejavnosti, med katerimi je bilo tudi zaposlovanje pri železnici, pa so bili preskromni viri za potrebe prebivalstva. Povirsko in širše območje sežanskega okrajnega glavarstva je kljub napredovanju nekaterih gospodarskih branž, kot je bilo kamnoseštvo, ostajalo v osnovi ruralno in je gravitiralo na Trst ter druga bližja industrijska središča. Izseljevanje je bilo zato pogosta izbira in je, kot kažejo statistike, močno vplivalo na demografski razvoj. Migracija je bila sestavni element ekonomske in družbene strategije. Že v 18. stoletju najdemo v Trstu številne priseljence iz povirske prafare. Moški so opravljali najrazličnejša, večinoma nekvalificirana dela. Ženske so prihajale v dekliških letih služit in na ta način razbremenile bilanco oz. prispevale $\mathrm{k}$ dohodku izvornih družin ter si prislužile sredstva za svoje življenjske načrte. Izseljevanje se je v teku 19. stoletja še povečalo, $v$ zadnjih desetletjih pa se je obrnilo tudi proti drugim ciljem. Nekatere ženske so se priključile toku t. i. »aleksandrinstva«, ki je v Egiptu našlo bolje plačan trg hišnega dela. Moški so se v začetku 2o. stoletja, na vrhuncu prekooceanskega izseljevanja, odpravljali v Severno Ameriko (Skrinjar 2006). Prevladovale so vsekakor migracije na krajše razdalje, proti regionalnim središčem intenzivnega gospodarskega 
razvoja. Razširjeno je bilo zaposlovanje $\mathrm{v}$ pristanišču pri nakladanju, razkladanju in razvažanju ladijskih tovorov. Delali so tudi po ladjedelnicah v Trstu, Tržiču in Pulju kot poklicni delavci, na primer tesarji, kovači in mizarji (Pahor 1976). Pri tem je šlo za različne oblike mobilnosti. Eni so na delo odhajali sezonsko, drugi so bili stalno zaposleni v Trstu in so se domov vračali konec tedna, večji del izseljevanja pa je bil trajnega tipa. Izviralo ni samo iz omejenih perspektiv obstoja $\mathrm{v}$ okviru vaškega gospodarskega in družbenega sistema. Prehajanje $v$ mesto je bilo tudi odzivanje na priložnosti, ki jih je mesto ponujalo, izbira $v$ želji po družbeni mobilnosti in prestopu iz tradicionalnega v modernejše, mestno življenjsko okolje. Priseljenci s Krasa so bili pomembna komponenta tržaškega prebivalstva in $\mathrm{v}$ desetletjih pred prvo svetovno vojno so bili dobro zastopani tako $\mathrm{v}$ delavskih kot $\mathrm{v}$ malomeščanskih slovenskih vrstah.

\section{Zaključek}

V svoji študiji o kulturni krajini Krasa Panjek izpostavlja, kako si kraške krajine in ekonomije, ki jo je oblikovala vsaj od novega veka dalje, ni mogoče razlagati zgolj v luči agrarnega izkoriščanja teritorija. Upoštevati je treba tudi neagrarne dejavnosti prebivalstva, ki so $\mathrm{z}$ agrarnimi tvorile integriran kmečki gospodarski sistem (Panjek 2015). Ta sistem je imel med svojimi najvplivnejšimi zunanjimi dejavniki mesto Trst, ki je prestavljalo trg agrarnih proizvodov in hkrati s svojo trgovsko, pomorsko in drugo ekonomijo generator priložnosti neagrarnega dohodka. Potencial in vpliv mesta na razvoj zaledja se je eksponencialno večal po proglasitvi prostega pristanišča na začetku 18. stoletja. V tej luči si je treba razlagati tudi razvoj prebivalstva. Kraške vasi v tržaški občini so bile v kontekstu razmerja med mestom in njegovim podeželjem zaradi neposredne bližine in pripadnosti mestnemu upravnemu ozemlju v privilegiranem položaju. V času proste luke je kmečko prebivalstvo uživalo carinske in druge pravne privilegije ter zaščito gospodarsko najdonosnejših proizvodov. Integracija med agrarno ekonomijo in neagrarnimi dejavnostmi je tu lahko prišla logistično najbolje do izraza v najrazličnejših kombinacijah. Število prebivalstva je zahvaljujoč kombiniranju različnih oblik dohodka v povezavi z mestno ekonomijo presegalo gospodarsko nosilnost samih agrarnih virov. Tržaški policijski ravnatelj Antonio Pittoni je v zvezi s tem že leta 1786 poročal dvorni pisarni, da se kmetje tržaškega podeželja napajajo v mestnem bogastvu in da je v vaseh, kot sta Križ in Prosek, mogoče naleteti na hiše gosposkega izgleda. Prebivalci tržaškega podeželja naj ne bi poznali revščine in mnogi naj bi bili 
»bogati . Temu bogastvu pa so botrovali neagrarni viri dohodka in kmetijstvo naj bi bilo zaradi tega zanemarjeno (Dorsi 1989, 143-5). Ekspanzija mesta je, kot smo videli, spodbudila prestrukturiranje agrarnih dejavnosti, njegova bližina in prometne povezave pa so dovoljevale dinamično igro kombiniranja agrarnih in neagrarnih virov. Ti so v zadnjem delu obravnavanega obdobja $v$ večjih vaseh pridobivali na pomenu in ustvarjali sloje nekmečkega prebivalstva.

Tudi vasi povirske prafare so živele $\mathrm{v}$ simbiozi s Trstom in izkoriščale možnosti integracije med agrarnimi in neagrarnimi viri dohodka. Zaradi večje razdalje, pripadnosti drugim upravnim enotam in še drugih okoliščin pa je bilo usklajevanje agrarnega dohodka $\mathrm{z}$ viri mestne ekonomije v primerjavi s tržaškimi kraškimi vasmi omejeno in nezadostno, da bi lahko nosilo težo tako živahne naravne demografske rasti. Zato se je ta $\mathrm{v}$ veliki meri pretvarjala $\mathrm{v}$ stalno izseljevanje, počasno rast, stagnacijo ali celo padanje števila prebivalstva. Tako je, na primer, v Povirju število prebivalstva v 19. stoletju ostalo nespremenjeno, Sežana pa je imela kljub vlogi regionalnega središča $\mathrm{v}$ desetletjih pred prvo svetovno vojno celo najvišjo stopnjo izseljevanja. Tudi v kraškem delu tržaške občine so demografsko rast uravnavala migracijska gibanja, ki so bila odraz splošnih zgodovinskih trendov in specifičnih faz tržaškega razvoja. V obdobjih rasti mesta in njegove ekonomije je priseljence pritegnila tudi njegova neposredna kmečka okolica. Do srede 19. stoletja so ti zapolnjevali vrzeli negativnega naravnega salda. Ko se je naravna rast stabilizirala in je smrtnost ni več ogrožala, pa je izseljevanje odnašalo del prebivalstva, ki v vaškem družbenogospodarskem sistemu ni videlo zadovoljivih življenjskih perspektiv. Dejstvo, da je od osemdesetih let 19. stoletja in tudi v prvem desetletju 20. stoletja, ko se je število prebivalstva občutno povečalo, izseljevanje iz kraških vasi tržaške občine pojemalo, kaže, da je rast mesta v tem obdobju zagotavljala vzdržnost sistema integrirane ekonomije na njegovem neposrednem podeželju. Ob njej pa je rasel delež prebivalstva, pri katerem sta bili primarna dejavnost in glavnina dohodka neagrarna.

\section{Viri in literatura}

\section{Arhivski viri}

AGT: Archivio Generale del Comune di Trieste

Archivio Magistratuale 1815-1852 
AST, CF: Archivio di Stato di Trieste, Catasto Franceschino

Divača

Ležeče

Merče

Povir

Sežana

Štorje

ŠAK: Škofijski arhiv Koper

Župnija Povir, Krstne knjige 1623-1872

Župnija Povir, Smrtne knjige 1651-1915

Župnija Sežana, Krstne knjige 1778-1925

Župnija Sežana, Smrtne knjige 1778-1899

Župnija Divača, Krstne knjige 1786-189o

Župnija Divača, Smrtne knjige 1789-189o

Kaplanija Štorje, Krstne knjige 1802-189o

Kaplanija Štorje, Smrtne knjige 1802-1865

ZAŽB: Zgodovinski arhiv župnije Bazovica

Liber baptisatorum $1786-1841$ in $1842-1913$

Liber defunctorum 1786-1841 in 1842-1943

\section{Objavljeni viri}

Österreichische Statistik (1882-1914): Ergebnisse der Volkszählungen etc. Wien,

K.k. Statistische Central-Commission.

Band I, Heft 1 (1880);

Band XXXII, Heft 1, 2, 5(1890);

Band LXIII, Heft 1, 2;

Band LXIV, Heft 1, 2(1900);

Band 1 Neue Folge, Heft 1, 2;

Band 2 Neue Folge, Heft 1(1910).

\section{Literatura}

Blaznik, P., idr., ur. 1970. Gospodarska in družbena zgodovina Slovencev. Zgodovina agrarnih panog, zv. 1. Ljubljana: Slovenska akademija znanosti in umetnosti in Državna založba Slovenije. 
Brecelj, A., Z. Legiša in I. Vogrič. 1989. Nabrežinski kamnolomi. Trst: Založništvo tržaškega tiska.

Breschi, M., A. Kalc in E. Navarra. 2001. »La nascita di una città. Storia minima della popolazione di Trieste (secc. XVIII-XIX).«V Storia economica e sociale di Trieste. I: La città dei gruppi 1719-1918, ur. R. Finzi in G. Panjek, 69-237. Trieste: Lint.

Brodmann, G. 1821. Memorie politico-economiche della città e territorio di Trieste della penisola d'Istria della Dalmazia fu veneta di Ragusi e dell'Albania ora congiunti all'austriaco impero. Venezia: Tipografia Alvispopoli.

Bufon, M., in A. Kalc. 1991. Krajevni leksikon Slovencev v Italiji. Tržaška pokrajina. Trst: Založništvo tržaškega tiska.

Della Bona, G. B. 1856. Osservazioni ed aggiunte sopra alcuni passi dell'Istoria della Contea di Gorizia di Carlo Morelli di Schönfeld. Gorizia.

Dorsi, P. 1989. »'Libertà' e 'Legislazione'. Il rapporto del barone Pittoni sullo stato della città di Trieste e del suo Territorio (1786).« Archeografo Triestino 97: 137-85.

Faber, E. 1995. Litorale Austriaco: das österreichische und kroatische Küstenland 170o-1780. Trondheim, Graz: Historisk Institut, Steiermärkisches Landesarchiv.

Iancis, P. 2001. "Manifattoti e lavoranzia«. Le forme del lavoro a Gorizia nel Settecento. Gorizia: Edizioni della Laguna.

Kalc, A. 1999. »Tržaško podeželje in policijski red iz leta 1777. Kratek sprehod med črko in stvarnostjo." Annales. Series historia et sociologia 9 (2): 271-88.

Kalc, A. 2004. »Žensko prebivalstvo v Trstu leta 1775: nekaj socialno-demografskih in gospodarskih vidikov ter metodoloških vprašanj.« Zgodovinski časopis $58(3-4)$ : 337-76.

Kalc, A. 2005. »Vinogradništvo in trgovina z vinom na Tržaškem v 18. stoletju kot področje spora med 'tradicionalnim' in 'inovativnim'."Annales. Series historia et sociologia 15 (2): 291-308.

Kalc, A. 2008. "Konskripcija tržaškega Teritorija iz let 1777/78.« Zgodovinski časopis 62 (1-2): 29-44.

Kalc, A. 2011. »Trst v času Ilirskih provinc: nekaj demografskih vidikov.« V Pirjevčev zbornik: poti zgodovine med severnim Jadranom, srednjo in vzhodno Evropo: ob 7o. obletnici akad. prof. dr. Jožeta Pirjevca, ur. G. Bajc in B. Klabjan, 37-47. Koper: Univerzitetna založba Annales, 37-47. 
Kalc, A. 2013. »Vidiki razvoja prebivalstva Goriške-Gradiške v 19. stoletju in do prve svetovne vojne."Acta Histriae 21 (4): 683-706.

Kandler, P. 1846. »Del Territorio di Trieste.«L'Istria, 25. 6., 180-82.

Kos, M. 1954. Srednjeveški urbarji za Slovenijo. Urbarji Slovenskega Primorja. Ljubljana: Slovenska akademija znanosti in umetnosti.

Merkú, P. 1994. Il »Libro di perticationi« del notaro Giusto Ravizza (1525): il testo e l'analisi dei nomi personali, di istituzioni e di luoghi. Trieste: Devin.

Montanelli, P. 1905. Il movimento storico della popolazione di Trieste. Trieste.

Navarra, E. 1993. Famiglie e terre a Barcola fra '7oo e '8oo. Trieste.

Pahor, M. 1976. »Kraška vas Povir. Primer simbioze med kopnim in morjem.« Goriški letnik 3: 97-123.

Pahor, M., ur. 1987. L'uomo e la vite = Človek in trta. Trst: Provincia di Trieste.

Panjek, A. 2012. »Goriške duše 1566: prostorska, demografska in socialna struktura prebivalstva v ekonomski konjunkturi.« Acta Histriae 20 (3): 459-84.

Panjek, A. 2015. Kulturna krajina in okolje Krasa. Koper: Založba Univerze na Primorskem.

Semerani, L., D. De Rosa in L. Celli. 1970. Il Carso Triestino: Santa Croce. Trieste: Libreria.

Skrinjar, P. 2006. Sežana. Sonce nad prestolnico Krasa. Sežana: Ad Pirum.

Valenčič, V. 1962. „Štetje prebivalstva leta 1754 v predjožefinski ljubljanski škofiji in njegovi rezultati.« Zgodovinski časopis 16 (1-4): 27-53.

Valenčič, V. 1996. »Prebivalstvo po župnijah na Kranjskem v letih 1778 in okrog 1780.«Zgodovinski časopis 50 (1): 53-63.

Volpi Lisjak, B. 1995. Slovensko pomorsko ribištvo skozi stoletja od Trsta do Timave. Trst: Mladika.

Volpi Lisjak, B. 1996. La spettacolare pesca del tonno attraverso i secoli nel Golfo di Trieste. Trieste: Mladika.

Zubini, F. 2007. Opicina: ameno villaggio dell'altipiano, ai tempi dell'impero. Triste: Italo Svevo.

Zwitter, F. 1936. Prebivalstvo na Slovenskem od XVIII. stoetja. do današnjih dni. Ljubljana. 